\title{
Low-temperature thermochronometry along the Kunlun and Haiyuan Faults, NE Tibetan Plateau: Evidence for kinematic change during late-stage orogenesis
}

\author{
Alison R. Duvall, ${ }^{1}$ Marin K. Clark, ${ }^{2}$ Eric Kirby, ${ }^{3,4}$ Kenneth A. Farley, ${ }^{5}$ \\ William H. Craddock, ${ }^{3,6}$ Chuanyou Li, ${ }^{7}$ and Dao-Yang Yuan ${ }^{8}$ \\ Received 20 January 2013; revised 4 July 2013; accepted 1 August 2013; published 1 October 2013.
}

[1] The Tibetan Plateau is a prime example of a collisional orogen with widespread strike-slip faults whose age and tectonic significance remain controversial. We present new low-temperature thermochronometry to date periods of exhumation associated with Kunlun and Haiyuan faulting, two major strike-slip faults within the northeastern margin of Tibet. Apatite and zircon (U-Th) $/ \mathrm{He}$ and apatite fission-track ages, which record exhumation from $\sim 2$ to $6 \mathrm{~km}$ crustal depths, provide minimum bounds on fault timing. Results from Kunlun samples show increased exhumation rates along the western fault segment at circa 12-8 Ma with a possible earlier phase of motion from $\sim 30-20 \mathrm{Ma}$, along the central fault segment at circa 20-15 Ma, and along the eastern fault segment at circa 8-5 Ma. Combined with previous studies, our results suggest that motion along the Haiyuan fault may have occurred as early as $\sim 15 \mathrm{Ma}$ along the western/central fault segment before initiating at least by $10-8 \mathrm{Ma}$ along the eastern fault tip. We relate an $\sim 250 \mathrm{~km}$ wide zone of transpressional shear to synchronous Kunlun and Haiyuan fault motion and suggest that the present-day configuration of active faults along the northeastern margin of Tibet was likely established since middle Miocene time. We interpret the onset of transpression to relate to the progressive confinement of Tibet against rigid crustal blocks to the north and expansion of crustal thickening to the east during the later stages of orogen development.

Citation: Duvall, A. R., M. K. Clark, E. Kirby, K. A. Farley, W. H. Craddock, C. Li, and D.-Y. Yuan (2013), Low-temperature thermochronometry along the Kunlun and Haiyuan Faults, NE Tibetan Plateau: Evidence for kinematic change during late-stage orogenesis, Tectonics, 32, 1190-1211, doi:10.1002/tect.20072.

\section{Introduction}

[2] Major changes in structural style are often observed during the later stages of convergent orogen development. These kinematic changes occur presumably in concert with topographic

Additional supporting information may be found in the online version of this article.

${ }^{1}$ Department of Earth and Space Sciences, University of Washington, Seattle, Washington, USA

${ }^{2}$ Department of Geological Sciences, University of Michigan, Ann Arbor, Michigan, USA.

${ }^{3}$ Department of Geosciences, Pennsylvania State University, University Park, Pennsylvania, USA.

${ }^{4}$ Now at College of Earth, Ocean and Atmospheric Sciences, Oregon State University, Corvallis, Oregon, USA

${ }^{5}$ Division of Geological and Planetary Sciences, California Institute of Technology, Pasadena, California, USA

${ }^{6}$ Now at U.S. Geological Survey, Reston, Virginia, USA.

${ }^{7}$ State Key Laboratory of Earthquake Dynamics, Institute of Geology, China Earthquake Administration, Beijing, China.

${ }^{8}$ Lanzhou Institute of Seismology, China Earthquake Administration, Lanzhou, China.

Corresponding author: A. R. Duvall, Department of Earth and Space Sciences, University of Washington, Rm. 070 Johnson Hall, Box 351310 , Seattle, WA 98195-1310, USA. (aduvall@uw.edu)

(C2013. American Geophysical Union. All Rights Reserved. 0278-7407/13/10.1002/tect.20072 growth or attainment of maximum elevation and are often expressed at the orogenic scale by way of transition from predominant thrust faulting to strike-slip or normal faulting. Examples include the Arabia-Asia collision zone [Copley and Jackson, 2006], the Carpathian and Dinarides-Hellenides mountain ranges [Nemcok, 1993; Pincha, 2002, 2011], the initiation of Basin and Range extension in the Western U.S. following the Sevier and Laramide orogenies [Coney and Harms, 1984; Sonder et al., 1987], and the onset of strike-slip and normal faulting within the Tibetan Plateau [Armijo et al., 1986, 1989; Mercier et al., 1987; Yin et al., 1994; Blisniuk et al., 2001; Taylor et al., 2003]. Despite clear observations of temporal variability in structural styles, paucity of fault ages inhibits our ability to tell if such changes are synchronous across an orogen, and if so, whether or not they have a common cause. As a result, debate surrounds the proposed mechanisms that explain these shifts, with ideas ranging from external drivers, such as changes in plate boundary forces, to internal drivers, such as changes in crustal thickness and gravitational potential energy, as well as heating, weakening, and flow of the crust [e.g., England and Houseman, 1989; Bird, 1991; Jones et al., 1996; Rey et al., 2001; Allen et al., 2004; Copley and Jackson, 2006; Gemmer and Houseman, 2007].

[3] The long-term geologic significance of strike-slip faulting in Tibet is controversial, in part because timing of many of the 


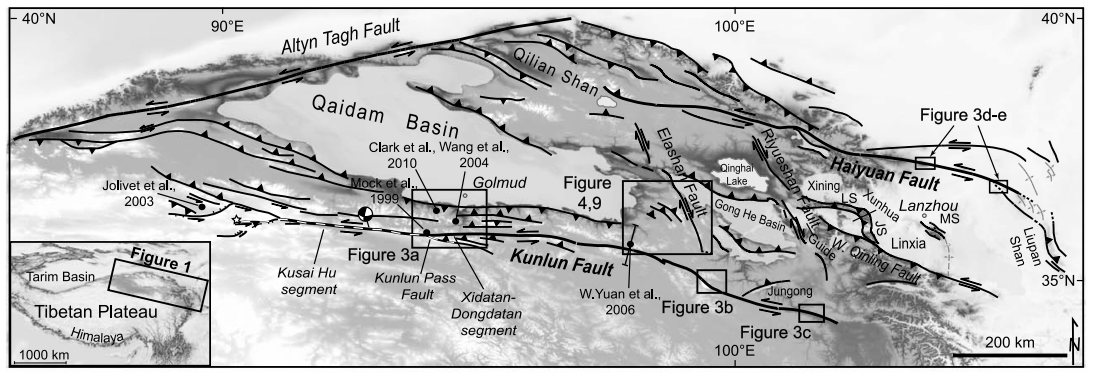

Figure 1. Shaded relief map of study area with faults and sample locations (sample ID numbers in parentheses) created from $90 \mathrm{~m}$ SRTM elevation data. Generalized faults of northern Tibetan Plateau margin compiled from published sources [GBGMR Gansu Province, 1989; Van Der Woerd et al., 2002; Jolivet et al., 2003; Pan et al., 2004; Yin et al., 2002, 2007, 2008a, 2008b; Bovet et al., 2009; Zheng et al., 2010; Huang et al., 2011] and original field observations. The rupture length of the Mw $\sim 7.8$ Kokoxili earthquake (14 November 2001) is shown by a white dashed lined, with centroid focal sphere (Harvard) and small white star at the hypocenter (USGS). Inset shows broader Tibetan Plateau region.

major faults remains unknown. Most agree that the numerous strike-slip faults within this region relate in some way to the Cenozoic collision of the Indian and Eurasian continents [Molnar and Tapponnier, 1975, Figure 1] but questions still remain as to how these faults evolved and why. Strike-slip faulting that develops during the later stages of orogeny could indicate the involvement of topographic stresses as driving forces [Burke and Sengor, 1986], whereas horizontal motion that accompanies thrust faulting early in collision history more likely relates to boundary conditions, such as the orientation of the converging plates [Sengor et al., 1985; Teyssier et al., 1995] or zones of preexisting weakness [Fitch, 1972].

[4] Two of the longest faults of the Tibetan Plateau, the Kunlun and the Haiyuan strike-slip faults, lie along the northeastern Tibetan Plateau margin (Figure 1). Together with the nearby Altyn Tagh Fault (Figure 1), these are arguably the most important active faults within this region, as they extend for great lengths $(>1000 \mathrm{~km})$, have high geodetic and Quaternary slip rates ( $\geq 10 \mathrm{~mm} / \mathrm{yr}$ along some fault segments) [Van der Woerd et al., 1998, 2000, 2002; Zhang et al., 2007], and have produced large-magnitude earthquakes during historic times. Although modern, Holocene, and Quaternary slip rates are reasonably well known [Kidd and Molnar, 1988; Zhang et al., 1991; Gaudemer et al., 1995; Kirby et al., 2007; Van der Woerd et al., 1998, 2000, 2002; Lasserre et al., 1999, Lasserre et al., 2002; Zhang et al., 2004; Cowgill, 2007; Harkins and Kirby, 2008; Cavalié et al., 2008; Li et al., 2009; Harkins et al., 2010; Kirby and Harkins, 2013], robust estimates of the age of Kunlun and Haiyuan faulting are lacking due to few piercing points in well-dated geologic units along fault traces. These strike-slip faults appear to overprint an earlier contractional deformation period [Jolivet et al., 2001; Sobel et al., 2001; Yin et al., 2002; Horton et al., 2004; Dupont-Nivet et al., 2004; Dai et al., 2006; Yin et al., 2008a; Dayem et al., 2009; Clark et al., 2010; Duvall et al., 2011; Wang et al., 2011b; Lin et al., 2011; Huang et al., 2011] that began shortly after the initiation of Indo-Eurasian collision (circa 55-45 Ma) [Rowley, 1996, 1998]. Thus, activity on the Kunlun and Haiyuan faults may represent a major change in structural style possibly related to Miocene initiation of extension and strike-slip faulting elsewhere within the plateau [e.g., Armijo et al., 1986, 1989; Mercier et al., 1987; Yin et al., 1994; Blisniuk et al., 2001; Taylor et al., 2003; Yin, 2010; Lease et al., 2011].
[5] The development of large-scale strike-slip faults in Tibet adds a particular challenge to characterizing long-term fault histories within this orogenic system. Pure strike-slip fault motion generally lacks association with regional mountain building and basin formation or the exhumation of deep rocks that can be readily used to determine faulting or deformation age. However, at the local scale, vertical motion associated with strike-slip faults has been recognized from field observations [e.g., Crowell, 1974; Biddle and Christie-Blick, 1985] and theoretical considerations [e.g., Chinnery, 1965; Bilham and King, 1989] since near the acceptance of plate tectonics. Secondary contractional and extensional structures related to distributed strain and relief generation around main strands of strike-slip faults (the PDZ or principal displacement zone) are widely recognized [Wilcox et al., 1973; Crowell, 1974; Woodcock and Fischer, 1986; Sylvester, 1988; McClay and Bonora, 2001]. The PDZ is a relatively narrow zone characterized by complex structures, many of which possess opposing orientations and dip-slip offset (Figure 2a). In addition, continental strike-slip faults, especially the long ones, rarely manifest as a simple linear strand. More often, they consist of a complex amalgamation of fault segments that regularly change orientation in sharp or diffuse bends, relay in en-echelon steps, join with other strike-slip faults at a single junction or spread out in a distributed fashion among multiple parallel splays, and terminate in either contractional or extensional structures at their tips (Figures $2 \mathrm{a}-2 \mathrm{e}$ ). Such architectural complexity leads to vertical motions and appreciable range growth or basin formation, as well as later tectonic inversions of ranges and basins (e.g., "porpoise tectonics" [Crowell, 1974] or "yo-yo tectonics" [Umhoefer et al., 2007]).

[6] Early work related to secondary structures associated with strike-slip faulting focused mainly on syntectonic basin sediments [e.g., Christie-Blick and Biddle, 1985], but the advent of low-temperature thermochronology has opened up new avenues to explore the vertical uplift and subsequent exhumation of mountain ranges adjacent to strike-slip faults. Such studies have yielded insights into the slip rate, strain partitioning, initiation, and re-organization of major strike-slip fault systems including the San Andreas [Spotila et al., 2007], Alpine [Batt and Braun, 1999], 


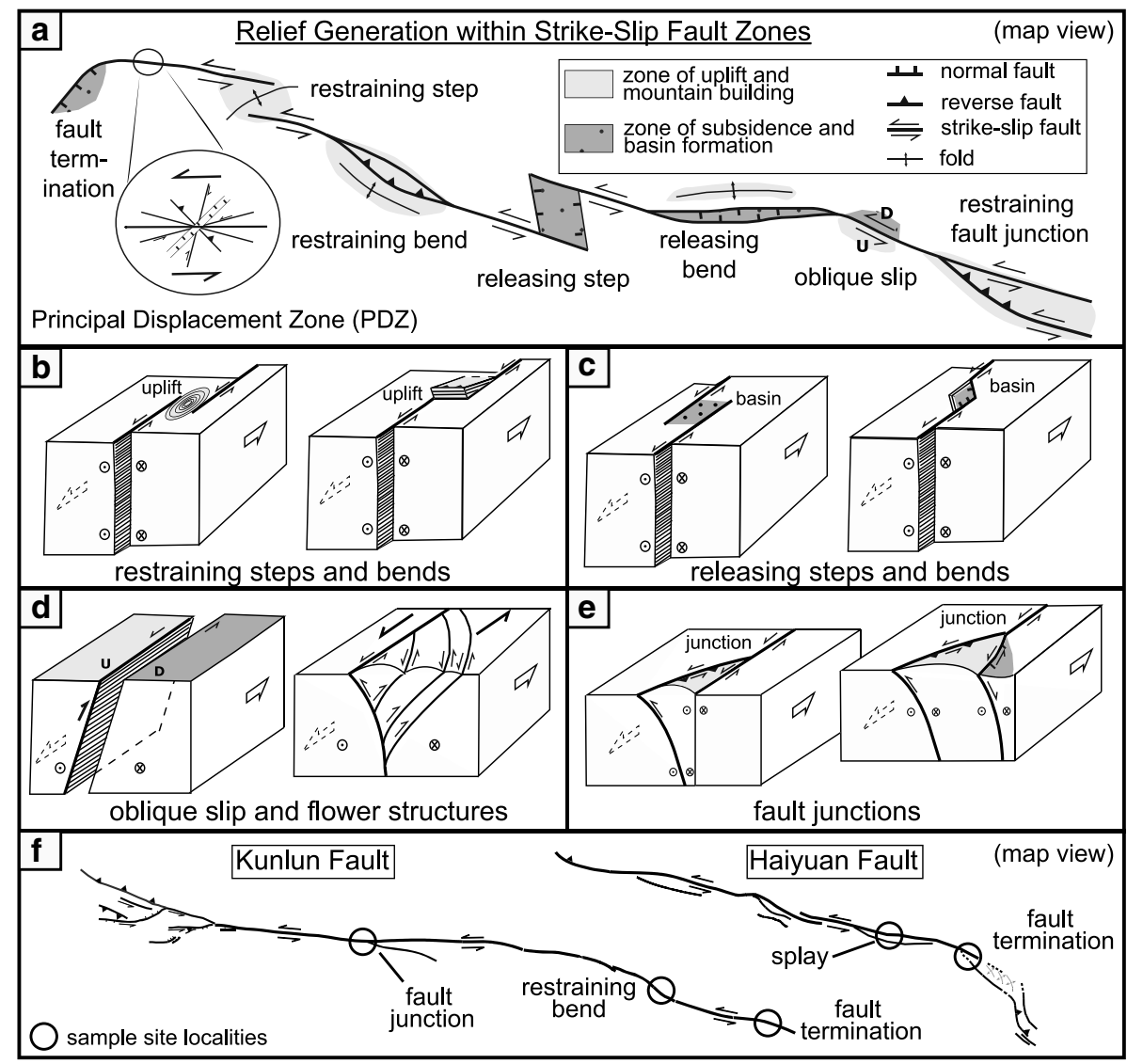

Figure 2. Generalized diagrams depicting structural complexity, vertical motion, and relief generation within typical strike-slip systems. (a) Map view and (b-e) block diagrams showing along-strike architecture and zones of relief generation for a typical continental strike-slip fault. Modified after illustrations in Christie-Blick and Biddle [1985], Aydin and Nur [1985], and Spotila et al. [1998]. (f) Map view sketch depicting the architecture of the Kunlun and Haiyuan Faults. Kunlun Fault segments from Van Der Woerd et al. [2002] and Haiyuan Fault segments from Stirling et al. [1996]. Open circles correspond to sample locations for this study (see Figure 3 for detailed geology). Note that these samples were collected at fault junctions, bends in segments, splay zones, and fault termination and that these locations correspond with zones of local relief.

and Denali [Benowitz et al., 2011]. Despite its usefulness to strike-slip faults, low-temperature thermochronology has yet to be applied to transcurrent faults in central Asia.

[7] In this paper, we provide minimum estimates of timing of Kunlun and Haiyuan Fault motion by dating periods of exhumation associated with faulting using low-temperature thermochronometry in order to address the central questions of whether and how local changes in fault patterns relate to one another or to a broader Tibetan Plateau-wide reorganization of deformation.

\section{Background}

\subsection{Geologic Setting}

[8] The left-lateral Kunlun Fault extends roughly E-W for $\sim 1500 \mathrm{~km}$ marking the boundary between the low-relief Tibetan Plateau highland to the south and basins and ranges of the plateau margin to the north (Figure 1). The Qaidam Basin, which is located $\sim 75 \mathrm{~km}$ north of the Kunlun Fault (Figure 1), contains a maximum of $\sim 15 \mathrm{~km}$ of Cenozoic sediment [Bally et al., 1986; Zhou et al., 2006; Yin et al., 2008a]. Internal deformation within this basin is documented [Yin et al., 2008b], although in general, strong basement [Zhou et al., 2006; Zhu et al., 1995] is thought to underlie this relatively intact depocenter (Figure 1). To the east and in sharp contrast, the northeastern plateau margin is characterized by several small to intermediate size rhomb-shaped terrestrial basins (e.g., Linxia, Xining, Xunhua, Guide, and Gonghe Basins) separated from one another by intervening N-S and E-W oriented mountain ranges above basement-cored reverse faults that place Archean-Triassic rocks on top of younger Cenozoic strata (Figure 1). Geologic units within these basins include alternating conglomerates, sandstones, and finer-grained lake deposits that are mainly Cenozoic in age, although Cretaceous sedimentary rocks are exposed in several localities throughout this region [Pan et al., 2004]. Based on sedimentology, stable isotopes, structural arguments, and paleomagnetic data, it has been suggested that these individual basins were linked in a larger basin system [Zhai and Cai, 1984; Horton et al., 2004] that then became isolated from one another by deformation and topographic development as recently as the middle to late Miocene [Zheng et al., 2003; Fang et al., 2005; Yan et al., 2006; Lease et al., 2007; Hough et al., 2011; Lease et al., 2011; 
Zhang et al., 2011; Craddock et al., 2011]. To the northeast, the Haiyuan left-lateral strike-slip fault, which is oriented parallel to the Kunlun Fault and also of great length $(\sim 1000 \mathrm{~km})$, marks the boundary between the basins and ranges of the greater Linxia area and a vast region of Cenozoic folding, thrust, and strike-slip faulting to the north and west known as the Qilian Shan (Figure 1).

[9] The Dulan-Chaka Highland (DCH), a region underlain by $\sim 60 \mathrm{~km}$ thick crust [Meyer et al., 1998] and with an average elevation of $\sim 4400 \mathrm{~m}$, lies in between the Kunlun and Haiyuan Faults and stands as a topographic divide between the Qaidam Basin to the west and the rhomb-shaped basins of the greater Linxia region to the east (Figure 1). The Kunlun Fault locally bounds the DCH to the south and the right-lateral Elashan Fault (also known as Wenquan Fault) comprises the eastern boundary (Figure 1). En-echelon reverse faults within the $\mathrm{DCH}$ region are thought to relate to right-lateral Elashan Fault activity [Wang and Burchfiel, 2004]. Based on age and offset estimates of terrace risers displaced by the Elashan Fault, Yuan et al. [2011] determine average slip rates of $1.1 \pm 0.3 \mathrm{~mm} / \mathrm{yr}$ and a fault initiation age of $9 \pm 3$ Ma using 9-12 km of measured offset within Triassic rocks and assuming constant long-term slip rates during late Cenozoic time. The parallel Elashan and Riyueshan Faults (Figure 1) are thought to be antithetic right-lateral structures that accommodate shear in between the Kunlun and Haiyuan Faults through counterclockwise block rotation in a bookshelf or domino style [Duvall and Clark, 2010]. Thus, deformation and range growth within the $\mathrm{DCH}$ relates broadly to Kunlun and Haiyuan fault activity and studying the style and timing of faulting within this region offers additional constraints on major left-lateral slip.

\section{Approach and Methods}

[10] In this study, we target regions of deformation associated with Kunlun and Haiyuan fault motion and assume that local erosion rates increase in response to associated changes in base level driven by vertical motion near the fault. In order to ascertain the timing of increased erosion rate and by proxy, the timing of faulting, we use low-temperature thermochronometry, which provides a measure of how fast rocks move through the shallow crust [Reiners and Ehlers, 2005]. We constrain exhumation histories of rocks by measure of (U-Th)/He in apatite and zircon and fission tracks in apatite, systems which have relatively low effective closure and annealing temperatures $\left(\sim 55-75^{\circ} \mathrm{C}, \sim 200^{\circ} \mathrm{C}\right.$, and $\sim 100-120^{\circ}$ $\mathrm{C}$, respectively, depending on grain size, cooling rate, and effective uranium concentration [Gleadow and Duddy, 1981; Wolf et al., 1996; Farley, 2000; Reiners et al., 2002; Ketcham et al., 2007; Flowers et al., 2009]). Given average continental geothermal gradients, cooling ages typically record exhumation from $\sim 2$ to $6 \mathrm{~km}$ depths, thus, are useful in studying upper crustal processes [Zeitler et al., 1987; Wolf et al., 1996, 1998; Ehlers and Farley, 2003].

[11] Thermochronometry has been utilized successfully to assess the timing of fault initiation along dip-slip faults [e.g., Wagner and Reimer, 1972], as denudation rates commonly increase in response to relief generation by faulting. Although strike-slip faults by definition juxtapose crust laterally, vertical deformation also occurs commonly in conjunction with horizontal motion [e.g., Wilcox et al., 1973;
Crowell, 1974; Christie-Blick and Biddle, 1985; Aydin and Nur, 1985; Woodcock and Fischer, 1986; Sylvester, 1988; Stirling et al., 1996; Spotila et al., 1998; McClay and Bonora, 2001, see Figure 2]. Previous studies demonstrate that exhumation through the shallow crust associated with major strike slip faults is measurable by thermochronometry [e.g., Spotila et al., 1998, 2001, 2007]. Changes in fault geometry or boundary conditions over the life of the main fault can, however, lead to the migration of this ancillary deformation through time, such that secondary contractional and extensional structures may only be active during a limited period of fault motion. As a result, dating the deposition or exhumation of rock within a strike-slip fault zone potentially only reveals a local, short-lived event within the long-term geologic history of the main fault. In addition, creation of topography is not always instantaneous with the initiation of strike-slip faulting and erosional responses may lag faultinduced base-level changes in cases of less erosive climates and/or erosion-resistant rocks. In light of these potential limitations, we targeted several locations of high local relief along fault strike associated with fault junctions, terminations, restraining bends, or fault splays in order to investigate spatial variability in the timing of exhumation (Figure 2). Associated age estimates provide only minimum bounds on the timing of fault initiation.

[12] Two different sampling strategies were utilized in our study depending on the details of each site. In locations with high relief and well-exposed apatite- and zirconbearing rocks, samples were collected for low-temperature thermochronometry analysis along steep elevation transects. Age-elevation data along such transects reveal rates of cooling and in some cases, changes in cooling rate through time. In ideal circumstances, ages correlate with elevation such that higher-elevation samples are older and lower elevation samples are younger and relatively invariant. Such a marked transition from a shallower to steeper gradient along the profile (i.e., "break in slope") [e.g., Fitzgerald and Gleadow, 1990] is interpreted to reflect an increase in denudation rate, with older ages representing prefaulting slow erosion or stasis in the partial retention zone (PRZ) and younger ages defining a rapid cooling interval. Regions of lower relief, poor accessibility to higher altitudes, limited rock exposure, and/or lack of apatite- or zircon-bearing rocks at variable elevations required an alternative approach. At these sites, multiple thermochronometers with different closure temperatures were employed on a single sample to reveal a cooling history. This strategy is effective as long as denudation sufficiently exposes reset ages for multiple thermochronometry systems. In addition, simple Monte Carlo inversions of age results were utilized to determine viable thermal histories that are presented in section 5 .

[13] All sampled rocks were crushed and sieved using standard mineral separation techniques. Apatite and zircon were separated by exploiting differences in density and magnetic susceptibility. These phases were then handpicked at the University of Michigan and Caltech (respectively) and analyzed for (U-Th)/He ages at the Noble Gas Laboratory at Caltech using standard procedures [Farley and Stockli, 2002; Reiners et al., 2002]. All apatite fission-track analyses were performed by Apatite to Zircon, Inc. and ages were determined using a modified decay equation that includes calibration for the LA-ICP-MS using the Durango 


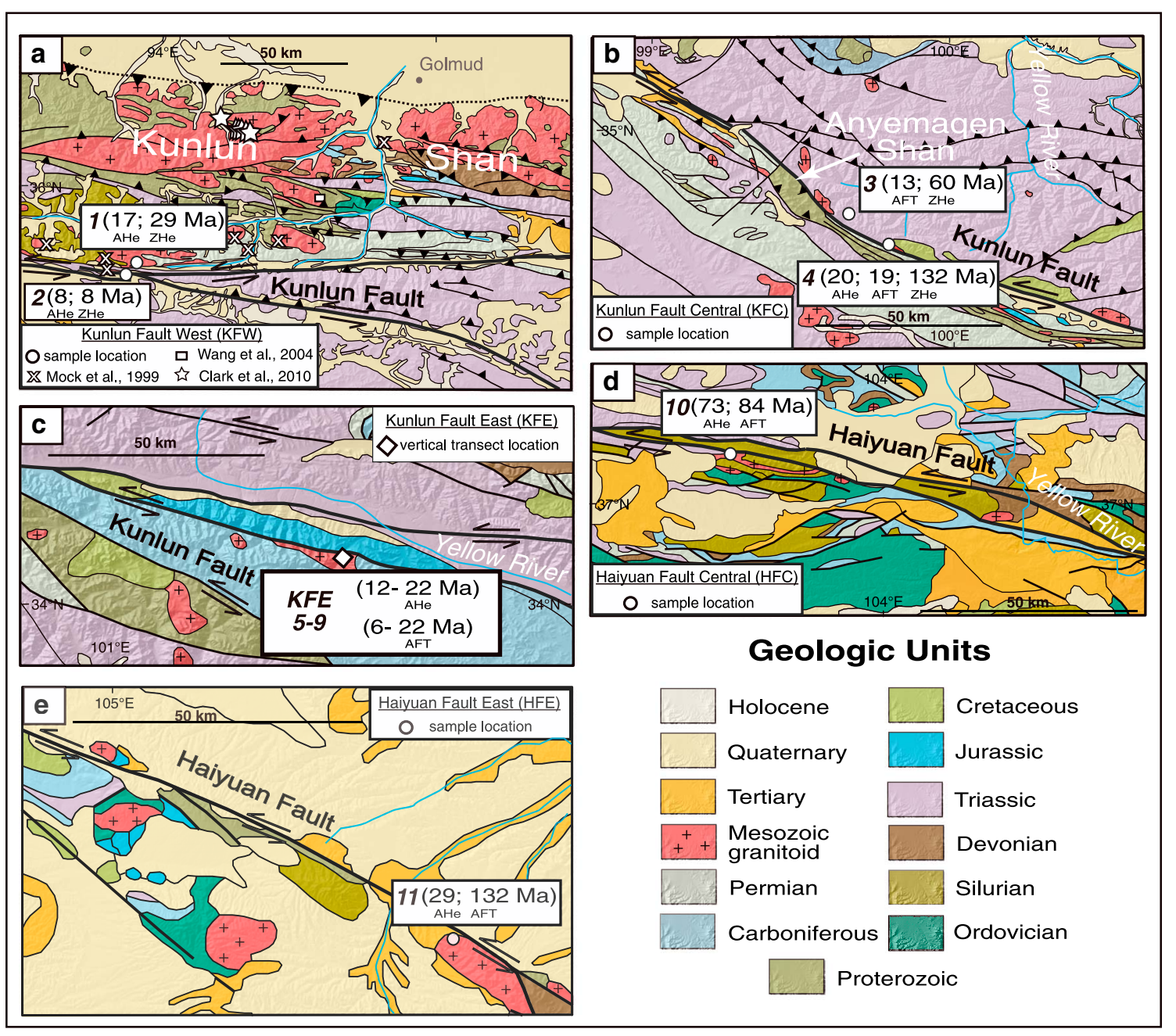

Figure 3. Generalized geologic maps of sample site locations. (a) Kunlun Fault west (KFW) site. Geology compiled from Kidd and Molnar [1988], QBGMR [1991], Pan et al. [2004], and Wu et al. [2009]. Apatite (black text) and zircon (gray text) helium ages shown for each sample location (\#1-2). Sample locations from previous studies shown by crosses $\left({ }^{40} \mathrm{Ar} /{ }^{39} \mathrm{Ar}[\right.$ Mock et al., 1999]), stars (AHe [Clark et al., 2010]), and squares (AFT [Wang et al., 2004], site approximately located). (b) Kunlun Fault central (KFC) site. Geology compiled from GBGMR [1989], Pan et al. [2004], and field observations. Apatite fission-track (bold italic black text) and zircon helium (gray text) ages shown for each sample location (\#3-4). (c) Kunlun Fault east (KFE) site. Geology compiled using Pan et al. [2004] and Harkins et al. [2010]. Youngest through oldest apatite helium (black text) and fission-track (bold italic black text) ages shown for an elevation transect (samples \#5-9). (d and e) Haiyuan central and east fault sites (HFC and HFE, respectively). Geology compiled using Pan et al. [2004] and field observations. Apatite helium (black text) shown for three elevation transects (ET1 \#12-16; ET2 \#17-21; ET3 \#22-26) and one horizontal transect ( 4100 m elevation \#27-30). Sample locations from previous AFT study shown by crosses [Yuan et al., 2006].

fluorapatite standard (fission-track age of $30.6 \mathrm{Ma}$ ) [Donelick et al., 2005]. Pooled AFT ages are reported unless the distribution of single-grain ages fails a conventional chi-square statistics test, in which case the central age is reported [e.g., Galbraith and Laslett, 1993; Gallagher et al., 1998]. Typically, four single-grain analyses were used to calculate mean helium ages and standard error $(2 \sigma)$, and 40 individual grains were measured to estimate a pooled fission-track age and $2 \sigma$ analytical error (Table S1 in the supporting information). Grains that yielded helium upon a second reheating step or "re-extract" following the initial laser heating and degassing of individual apatite grains were excluded on the basis of likely inclusions of higher-retentivity radiogenic phases such as zircon or monazite that were not seen during visual screening of each grain under magnification.

\section{Sample Site Descriptions and Results}

[14] We present new low-temperature thermochronometry ages from sites along the Kunlun and Haiyuan fault zones and within the neighboring Dulan-Chaka Highland (Figure 3,4). Thirty samples total were collected and 


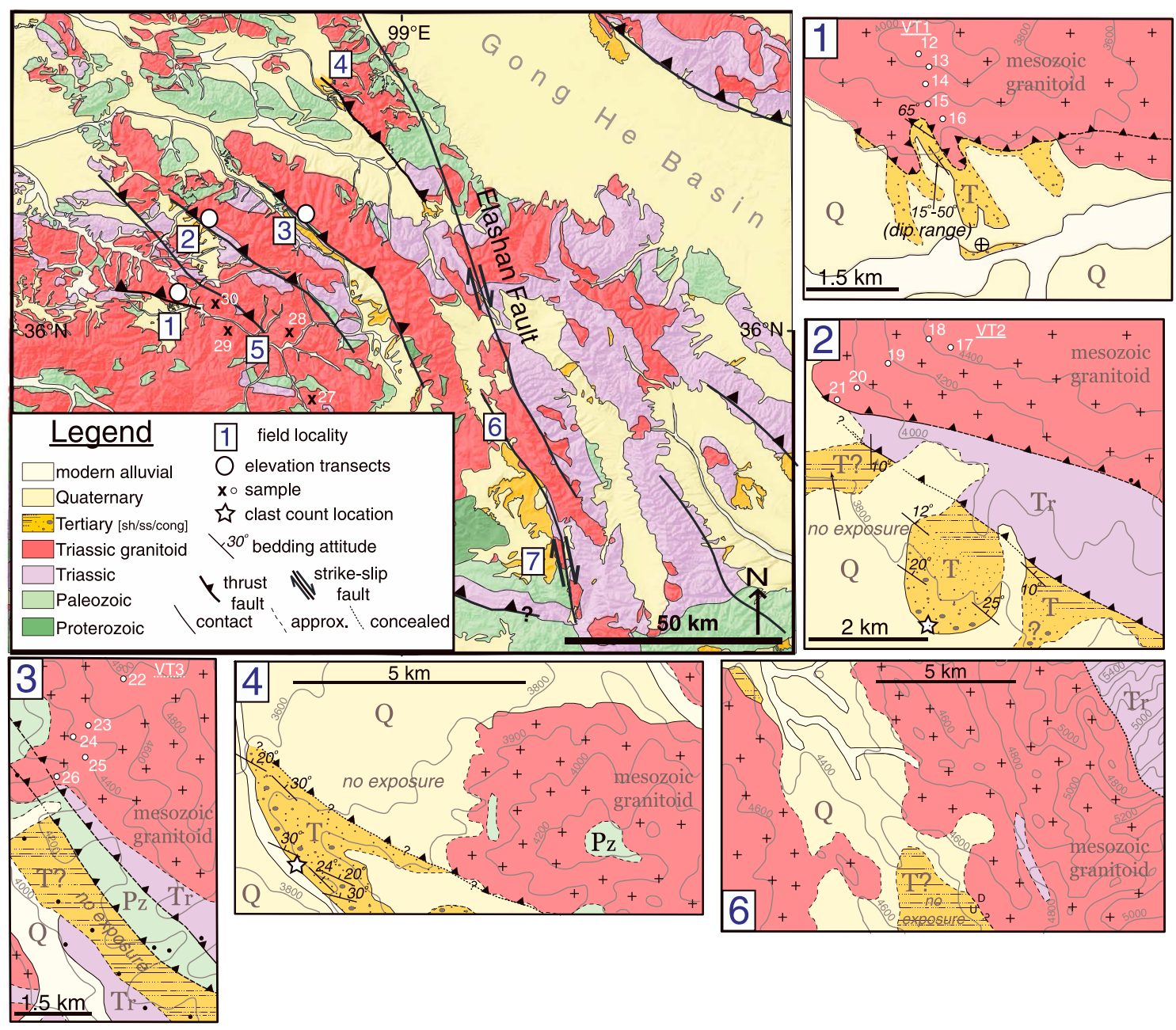

Figure 4. Geologic map of the Dulan-Chaka Highland draped over shaded relief. Map compiled from geologic mapping (this study) and GBGMR [1989]. Field localities visited shown by large white squares with site locality numbers. See map key for other symbols. Larger-scale maps show details of sites 1-4 and 6 . We found no Tertiary units exposed at sites 5 and 7.

analyzed for apatite helium (29 samples), apatite fission track (9 samples), and zircon helium (4 samples) (Table 1). The data set includes four elevation transects (five samples each), one horizontal transect (four samples total), and six single sample sites (Table 2). Below we describe the sample sites and dating results from across the study region. We begin to the southwest, along the Kunlun Fault, and then progress to the northeast discussing the DCH and finally the Haiyuan Fault samples. Within each subsection, we describe sample results systematically from west to east along fault strike.

\subsection{Kunlun Fault}

[15] We sampled Mesozoic rocks at three separate locations over a distance of $\sim 750 \mathrm{~km}$ along the Kunlun Fault (Figure 1 and Table 1). Two samples were collected along the fault's western segment, south and west of the city of Golmud (Figure 1). Sample site KFW1 (elevation 4755), which is also one of the sample localities in Mock et al.'s [1999] ${ }^{40} \mathrm{Ar}-{ }^{39} \mathrm{Ar}$ thermochronology study, is located just north of the Kunlun Fault along the southern edge of the Kunlun Shan and sample site KFW2 (elevation 4935) lies along the main fault strand adjacent to a major fault junction between first-order left-lateral Kunlun Fault segments and the Kunlun Pass Fault [Van der Woerd et al., 2000, 2002, Figures 1, 2f, and 3a]. Approximately $500 \mathrm{~km}$ along strike to the east, the central segment sites (KFC 3 and 4 -elevations 3877 and 3944, respectively) are located near to a large $(\sim 40 \mathrm{~km})$, broad restraining bend along the main Kunlun Fault (Figures 1-3). Thrust faults and folds, likely part of a duplex related to this fault geometry, create locally high topography that includes the $6282 \mathrm{~m}$ Anyemaqen massif. Farthest to the east, within the greater Anyemaqen Shan region of high topography and near to the eastern terminus of the fault [Kirby et al., 2007; Harkins et al., 2007], we collected five samples along a vertical relief elevation transect that ranges in elevation from 3659 to $4428 \mathrm{~m}$ (KFE5-9; Figure $2 \mathrm{f}$ and 3c). Because relief here centers on the Kunlun Fault and the sample site lies near to the eastern fault tip, we associate high topography with fault motion; however, the specific nature of the structural relationship between topographic growth and Kunlun strike-slip faulting remains uncertain.

\subsubsection{Kunlun Fault Thermochronometry Results}

[16] Two Triassic granitoid samples from locations KFW1 and KFW2 (Figure 3a) were analyzed for zircon and apatite 
Table 1. Sample Descriptions

\begin{tabular}{|c|c|c|c|c|c|c|c|c|c|}
\hline Location & Sample ID & Rock Type & Latitude & Longitude & Elev (m) & Thermchronometers & Ap He Rep ${ }^{a}$ & Ap FT Rep ${ }^{b}$ & $\mathrm{Zr} \mathrm{He} \mathrm{Rep}{ }^{c}$ \\
\hline \multirow{2}{*}{ Kunlun Fault West } & KFW1 & Granitoid & 35.724 & 93.933 & 4755 & $\mathrm{AHe}, \mathrm{ZHe}$ & 3 & - & 2 \\
\hline & KFW2 & Granitoid & 35.699 & 93.884 & 4935 & $\mathrm{AHe}, \mathrm{ZHe}$ & 3 & - & 2 \\
\hline \multirow[t]{2}{*}{ Kunlun Fault Central } & $\mathrm{KFC} 3$ & Flysch & 34.717 & 99.679 & 3877 & $\mathrm{AFT}, \mathrm{ZHe}$ & - & 39 & 3 \\
\hline & KFC4 & Diorite & 34.609 & 99.814 & 3944 & $\mathrm{AHe}, \mathrm{AFT}, \mathrm{ZHe}$ & 4 & 39 & 3 \\
\hline \multirow[t]{5}{*}{ Kunlun Fault East } & KFE5 & Granitoid & 34.094 & 101.508 & 4428 & $\mathrm{AHe}, \mathrm{AFT}, \mathrm{ZHe}^{\mathrm{d}}$ & 4 & 24 & - \\
\hline & KFE6 & Granitoid & 34.095 & 101.505 & 4259 & $\mathrm{AHe}, \mathrm{AFT}, \mathrm{ZHe}$ & 4 & 25 & - \\
\hline & KFE7 & Granitoid & 34.096 & 101.502 & 4091 & $\mathrm{AHe}, \mathrm{AFT}, \mathrm{ZHe}$ & 4 & 24 & - \\
\hline & KFE8 & Granitoid & 34.098 & 101.499 & 3841 & $\mathrm{AHe}, \mathrm{AFT}, \mathrm{ZHe}$ & 4 & 23 & - \\
\hline & KFE9 & Granitoid & 34.103 & 101.497 & 3659 & AHe, AFT, ZHe & 4 & 25 & - \\
\hline Haiyuan Fault Central & $\mathrm{HFC} 10$ & Granitoid & 37.114 & 103.66 & 2766 & $\mathrm{AHe}, \mathrm{AFT}$ & 4 & 39 & - \\
\hline Haiyuan Fault East & HFE11 & Granitoid & 36.52 & 105.554 & 2308 & $\mathrm{AHe}, \mathrm{AFT}$ & 4 & 37 & - \\
\hline \multirow[t]{5}{*}{ Dulan-Chaka Highland } & DCH12 & Granitoid & 36.073 & 98.405 & 4302 & $\mathrm{AHe}^{\mathrm{e}}$ & 4 & - & - \\
\hline & DCH13 & Granitoid & 36.071 & 98.407 & 4198 & $\mathrm{AHe}$ & 4 & - & - \\
\hline & DCH14 & Granitoid & 36.069 & 98.406 & 4093 & $\mathrm{AHe}$ & 4 & - & - \\
\hline & DCH15 & Granitoid & 36.066 & 98.406 & 3986 & $\mathrm{AHe}$ & 4 & - & - \\
\hline & DCH16 & Granitoid & 36.064 & 98.409 & 3867 & $\mathrm{AHe}$ & 4 & - & - \\
\hline \multirow[t]{5}{*}{ Dulan-Chaka Highland } & DCH17 & Granitoid & 36.256 & 98.472 & 4598 & $\mathrm{AHe}^{\mathrm{f}}$ & 4 & - & - \\
\hline & DCH18 & Granitoid & 36.258 & 98.467 & 4473 & $\mathrm{AHe}$ & 4 & - & - \\
\hline & DCH19 & Granitoid & 36.254 & 98.46 & 4276 & $\mathrm{AHe}$ & 4 & - & - \\
\hline & DCH20 & Granitoid & 36.25 & 98.454 & 4100 & $\mathrm{AHe}$ & 4 & - & - \\
\hline & DCH21 & Granitoid & 36.248 & 98.45 & 3924 & $\mathrm{AHe}$ & 4 & - & - \\
\hline \multirow[t]{5}{*}{ Dulan-Chaka Highland } & DCH22 & Granitoid & 36.28 & 98.719 & 4808 & $\mathrm{AHe}^{\mathrm{g}}$ & 4 & - & - \\
\hline & DCH23 & Granitoid & 36.277 & 98.712 & 4548 & $\mathrm{AHe}$ & 3 & - & - \\
\hline & DCH24 & Granitoid & 36.27 & 98.708 & 4407 & $\mathrm{AHe}$ & 3 & - & - \\
\hline & DCH25 & Granitoid & 36.267 & 98.711 & 4328 & $\mathrm{AHe}$ & 4 & - & - \\
\hline & DCH26 & Granitoid & 36.263 & 98.705 & 4160 & $\mathrm{AHe}$ & 4 & - & - \\
\hline \multirow[t]{4}{*}{ Dulan-Chaka Highland } & DCH27 & Granitoid & 35.856 & 98.769 & 4143 & $\mathrm{AHe}^{\mathrm{h}}$ & 4 & - & - \\
\hline & DCH28 & Granitoid & 36.015 & 98.751 & 4083 & $\mathrm{AHe}$ & 4 & - & - \\
\hline & DCH29 & Granitoid & 35.992 & 98.566 & 4123 & $\mathrm{AHe}$ & 4 & - & - \\
\hline & DCH30 & Granitoid & 36.067 & 98.513 & 4106 & $\mathrm{AHe}$ & 4 & - & - \\
\hline
\end{tabular}

${ }^{a}$ Number of apatite (U-Th)/He replicate analyses per sample.

${ }^{b}$ Number of apatite grains measured for fission tracks per sample.

${ }^{c}$ Number of zircon (U-Th)/He replicate analyses per sample.

${ }^{\mathrm{d}} \mathrm{KFE}$ elevation transect: KFE5-9.

${ }^{\mathrm{e}} \mathrm{DCH}$ elevation transect 1: DCH12-16.

${ }^{\mathrm{f}} \mathrm{DCH}$ elevation transect 2: DCH17-21.

${ }^{\mathrm{g}} \mathrm{DCH}$ elevation transect 3: DCH22-26.

${ }^{\mathrm{h}} \mathrm{DCH}$ horizontal transect: DCH27-30.

helium. Samples yielded zircon and apatite helium ages of 29 and $17 \pm 2 \mathrm{Ma}$ for KFW1 and $7.78 \pm 2.22$ and $8 \pm 1 \mathrm{Ma}$ for KFW2 (Figure 3a and Table 2). Overlapping KFW2 apatite and zircon helium ages indicate rapid cooling during this time interval. Biotite and K-feldspar ${ }^{40} \mathrm{Ar} /{ }^{39} \mathrm{Ar}$ data and modeling results from an earlier study of samples from this same region (Figures 1 and 3) [Mock et al., 1999] indicate temperatures between $160^{\circ} \mathrm{C}$ and $400^{\circ} \mathrm{C}$ from 140 to $30 \mathrm{Ma}$ followed by a cooling event $\left(9-15^{\circ} \mathrm{C} / \mathrm{Myr}\right)$ beginning sometime between 41 and $21 \mathrm{Ma}$.

[17] Fine-grained sandstone of the Songpan Garze flysch deposit (KFC3) and diorite (KFC4) was analyzed for apatite and zircon helium and apatite fission track. Results from sample KFC3 show a mean zircon helium age of $60 \pm 10$ $\mathrm{Ma}$ and an apatite fission-track pooled age of $12 \pm 1 \mathrm{Ma}$ (Table 2). Apatite of the appropriate size and quality for helium analysis was not available from this sample. Sample $\mathrm{KFC} 4$, which is located $\sim 40 \mathrm{~km}$ to east of $\mathrm{KFC} 3$ along strike (Figure $3 b$ ), has a zircon helium age of $132 \pm 4 \mathrm{Ma}$, an apatite fission-track central age of $21 \pm 2.4 \mathrm{Ma}$, and an apatite helium age of $20 \pm 1 \mathrm{Ma}$ (Table 2). Overlapping KFC4 apatite helium and fission-track ages indicate rapid cooling during this time interval.

[18] Farthest to the east along strike, Triassic granitoid rocks were collected along an elevation transect spanning $800 \mathrm{~m}$ of vertical relief over a horizontal distance of $\sim 1.5 \mathrm{~km}$ (KFE 5-9; Figures 1 and 3c). The KFE elevation transect generally shows a positive age/depth gradient for both the apatite helium (black circles) and apatite fissiontrack (gray diamonds) data, with a steep gradient in fissiontrack ages between 10 and 5 Ma suggesting an interval of rapid cooling during this time (Figure 5 inset). However, most of the apatite helium are older than the apatite fissiontrack ages (Table 2), which is unexpected given the difference in closure temperatures between the two systems $\left(\sim 55-70^{\circ} \mathrm{C}\right.$ and $\sim 100-110^{\circ} \mathrm{C}$, respectively). Large errors in apatite helium age due to poor replicate reproducibility as well as the occurrence of anomalous ages (a replicate with age greater than $30 \%$ different from the other three) among three of the five apatite helium samples (Table S1) may explain the apparent discrepancy between the helium and fission-track ages. Scatter of sample replicate ages that exceeds analytical uncertainty possibly relates to inclusions of a non-apatite uranium-bearing phase, zonation of $\mathrm{U}$ and Th, or implementation from neighboring high U-Th phases [Farley et al., 2011].

\subsection{Dulan Chaka Highland (DCH)}

[19] We targeted accessible areas within the Dulan-Chaka Highland indicated by previous studies to have preserved Cenozoic sediments [Qinghai Bureau of Geology and Mineral Resources (QBGMR), 1991; Wang and Burchfiel, 
Table 2. Thermochronometric Analyses Results

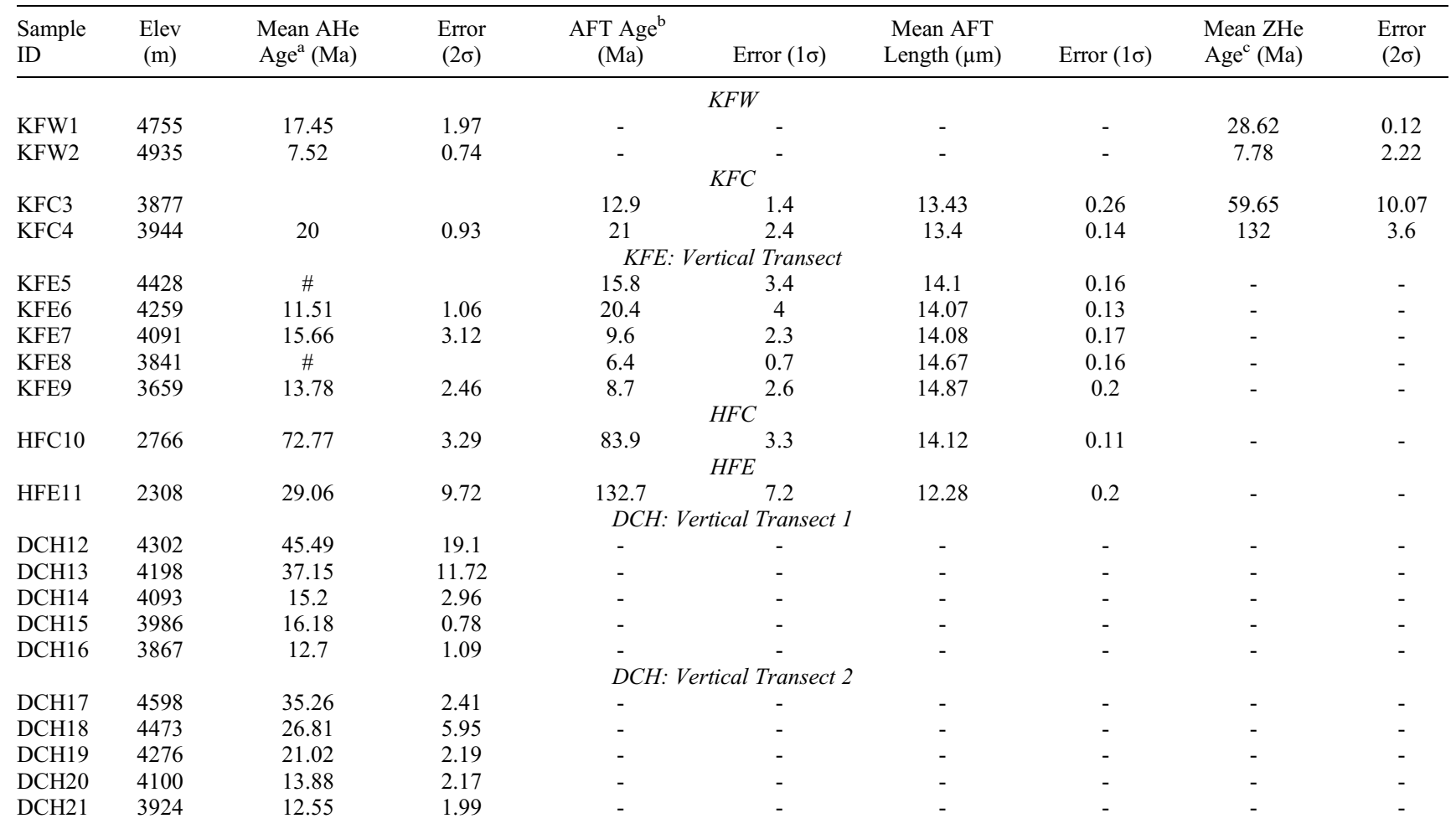

Sample IDElev (m) Mean AHe Age $\mathrm{e}^{\mathrm{b}}$ (Ma) Error $(2 \sigma)$ Pooled AFT Age $\mathrm{c}^{\mathrm{c}}$ (Ma) Error $(1 \sigma)$ Mean AFT Length $(\mu \mathrm{m})$ Error $(1 \sigma)$ Mean ZHe Age (Ma) Error $(2 \sigma)$

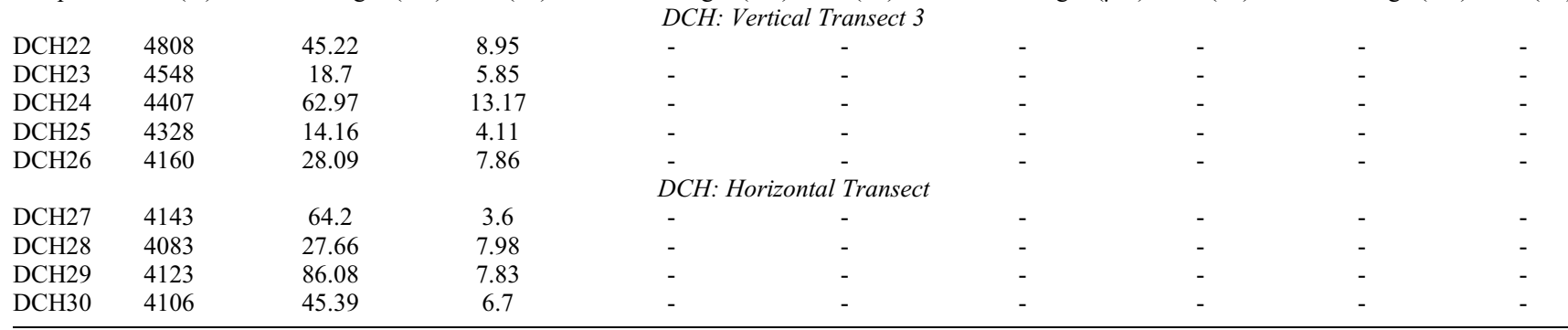

\footnotetext{
${ }^{a}$ Average of replicate ages. \# Replicates display poor reproducability with $>50 \%$ scatter. No mean age reported. See supporting information for all individual ages.

${ }^{b}$ AFT pooled age reported unless sample failed chi-square test, then the central age is reported. See supporting information for individual ages.

${ }^{\mathrm{c}}$ Average of replicates ages. See supporting information for individual ages.
}

2004], though rock exposure turned out to be poor or nonexistent at sites 3,5,6, and 7 (Figure 4 and see the supporting information for more detailed description of the sedimentary units). Mountain ranges within the DCH are of modest relief $(<800 \mathrm{~m})$ and composed of high-grade metamorphic rocks of early Proterozoic age and sedimentary and low-grade metamorphic rocks of Paleozoic and Triassic age which are intruded by numerous granitoid bodies of large extent [QBGMR, 1991] (Figure 4). In general, the southern flanks of ranges are bound by steep, northeast dipping reverse faults that place Paleozoic and Mesozoic basement over Cenozoic sedimentary rocks. Range-bounding fault surfaces are not exposed but we infer steep dips $\left(50-70^{\circ}\right)$ from the linear morphology of mountain fronts and the dip of minor outcrop-scale faults within Triassic rocks proximal to the range front. Fault offsets and subsurface fault geometries were not directly constrained. Basin deposits are generally gently to moderately deformed, striking roughly parallel to range fronts and dipping $10^{\circ}-30^{\circ}$ to the NE. Dips of beds in the footwall at locations 1 (see Figure S1) and 2 appear to shallow upsection, which suggests the possibility that sediment was deposited during progressive fault motion. Syntectonic deposition is also suggested by proximity of Tertiary deposits to fault-bounded ranges (Figure 4). Moreover, the large size and angular nature of the clasts support a relatively local origin. However, it is notable that the composition of clasts in outcrop (counted and described at sites 2 and 4 , see Figure 4 for locations) differs significantly from that of the local streams draining the surrounding bedrock, especially with regard to granitoid percentage (Figure 6). As a result, we propose that conglomerate clasts represent geologic unit(s) eroded from overtop the currently exposed granitoids as faulting, range growth, and erosion progressed.

[20] Three elevation transects spanning up to $700 \mathrm{~m}$ of vertical relief over horizontal distances $\leq 2.5 \mathrm{~km}$ were collected within hanging walls of steeply dipping reverse faults within the DCH (DCHET1-3; Figure 4). Granitoid rocks of the 


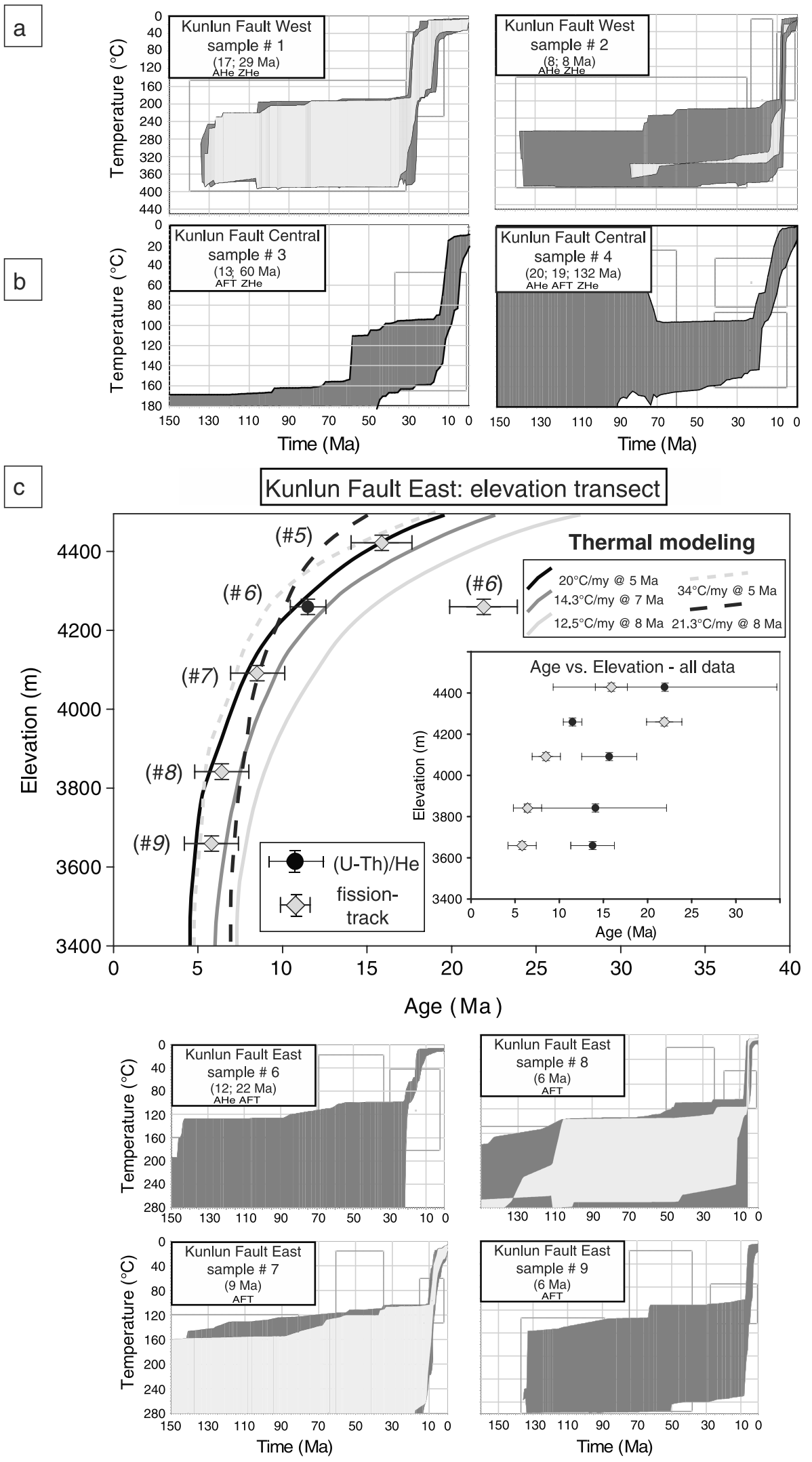

Figure 5 


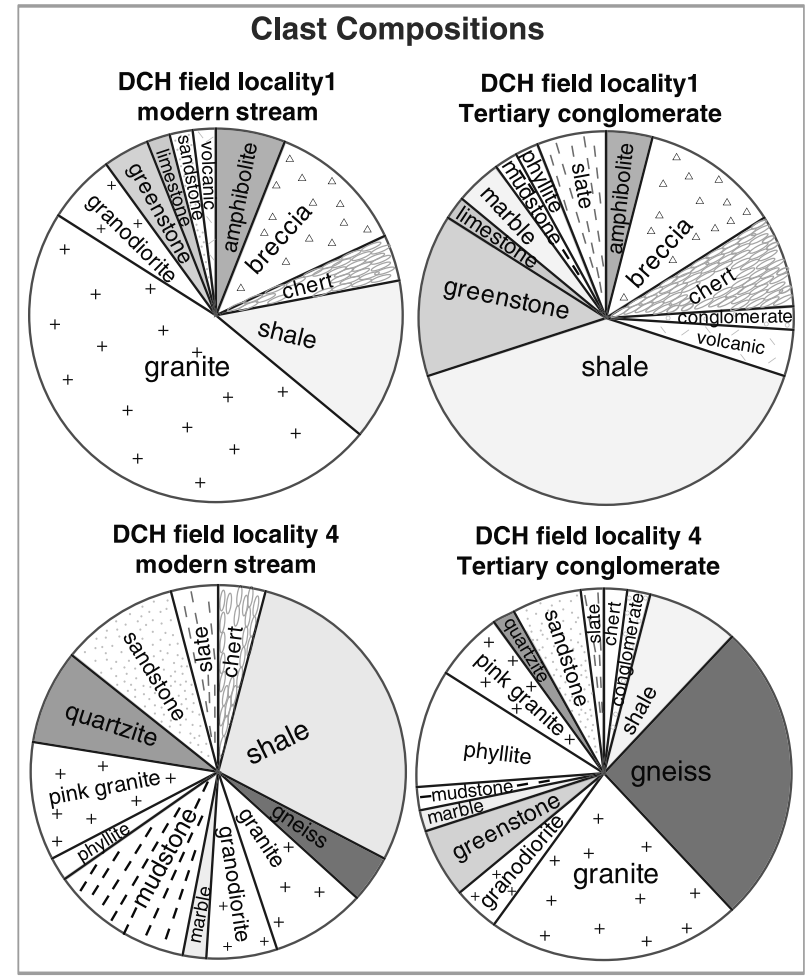

Figure 6. Pie charts demonstrating differences in clast composition between modern stream and local outcrop of Tertiary conglomerates from two locations within the Dulan-Chaka Highland (field sites 2 and 4). See Figure 4 for locations.

Triassic Kunlun Arc [Pan et al., 2004; Pullen et al., 2008] comprise all samples from this region. In the absence of structural or geomorphic horizons in the vicinity of sample transects, we assume vertical hanging wall movement with little to no internal deformation and interpret elevation as a proxy for depth. We also collected a horizontal transect comprising individual samples collected at constant elevation ( $4100 \mathrm{~m}, \mathrm{DCH} 27-30)$ away from mapped faults and mountain ranges in order to consider if increases in exhumation relate directly to fault motion.

\subsubsection{DCH Thermochronometry Results}

[21] Two of the three DCH elevation transects (ET1 and ET2; Figure 4) show regular positive age/depth gradients (Figure 7 and Table 2) from which we interpret monotonic cooling histories. Age/elevation data for ET1 and ET2 are defined by a gentle gradient from $\sim 45-35$ to $15 \mathrm{Ma}$, which is indicative of slow exhumation or stasis in the PRZ for helium diffusion during this interval (Figures $7 \mathrm{a}$ and $7 \mathrm{~b}$ ). In contrast, a steeper trend in age data beginning at $\sim 15 \mathrm{Ma}$ indicates an interval of increased cooling during this time (Figures $7 \mathrm{a}$ and $7 \mathrm{~b}$ ).

[22] Age data from ET3 do not show simple positive correlation with elevation (Figure 7c). Two replicates from this transect had to be excluded due to helium re-extracts and in general, samples along this transect had poorer than average reproducibility (Table S1), which makes data interpretation more difficult. Additionally, due to poor rock exposure, we do not have good structural control for this locality. Thus, it is possible that this region is more structurally complex than the others, which also may explain the more complicated age-elevation relationship. However, data from ET3 are consistent with ET1 and ET2 in that an increase in rate at $\sim 15 \mathrm{Ma}$ is permissible.

[23] Data results from the horizontal transect show variable ages ranging from $\sim 85$ to $27 \mathrm{Ma}$. We find no obvious relationship between age and distance or modern topography; however, these data do suggest that rapid exhumation along all of the vertically sampled ranges (ET1-3) relates to local faulting and not a broader exhumation process. Ages are older than predicted for an elevation of $4100 \mathrm{~m}$ (gray band, Figure $7 \mathrm{~d}$ ) assuming cooling histories similar to those of the elevation profiles.

\subsection{Haiyuan Fault}

[24] Approximately $200 \mathrm{~km}$ north of the Kunlun Fault, the parallel Haiyuan Fault dissects a highly arid, loess-draped landscape. We collected Mesozoic granitoid rocks at two localities along the fault (HFC10, HFE11; Figure 1) for apatite helium and fission-track analysis. At both sites, relief occurs proximal to the fault zone $(<2 \mathrm{~km})$ and thus, we associate this topography with fault motion. In general, however, sample-site options were more limited than along the Kunlun Fault due to overall less topographic relief along the fault (Figure 1) and fewer rocks that yield target minerals in close fault proximity (Figure 3). The HFC sample site sits between a fault splay and the main Haiyuan Fault at an elevation of $\sim 2800 \mathrm{~m}$ along the central fault segment and the HFE sample site is located $175 \mathrm{~km}$ east along strike near the eastern terminus of the fault at an elevation of $\sim 2300$ m (Figures $2 \mathrm{f}, 3 \mathrm{~d}$, and 3e).

Figure 5. Thermochronometry modeling results for the Kunlun Fault sites. Time (Ma) versus temperature $\left({ }^{\circ} \mathrm{C}\right)$ plots for samples along the (a) western Kunlun Fault segment and the (b) central Kunlun Fault segment. Swaths represent randomly generated cooling paths that fit the data to an acceptable (dark gray) and good (light gray) standard [Ketcham, 2005] (see text for details). All models constrained by at least two thermochronometric ages (shown in parentheses for each sample). AHe (black text), AFT (bold italic black text), and ZHe (light gray text). Biotite and potassium feldspar ${ }^{40} \mathrm{Ar} /{ }^{39} \mathrm{Ar}$ data $[$ Mock et al., 1999] provide additional higher-temperature constraints for samples 1 and 2 (KFW). (c) Top panel shows age/elevation plot of the eastern Kunlun Fault elevation transect (\#5-9). Horizontal error bars of helium ages (black circles) represent $2 \sigma$ uncertainty of mean age based on single-grain replicate ages from each sample and of fission-track ages (gray diamonds) represent $2 \sigma$ uncertainty of pooled age based on analytical error. Vertical error bars represent uncertainty of elevation (Tables 2 and S1). Inset shows entire suite of helium and fission-track data. Main plot shows a subset of reliable ages and time-temperature model results (solid and dashed lines). Helium samples with poor reproducibility and ages older than the fission-track age for the same sample (KFE5, 7-9) are not included. Bottom four samples show results of HeFTy thermal modeling for individual samples KFE6-9. 

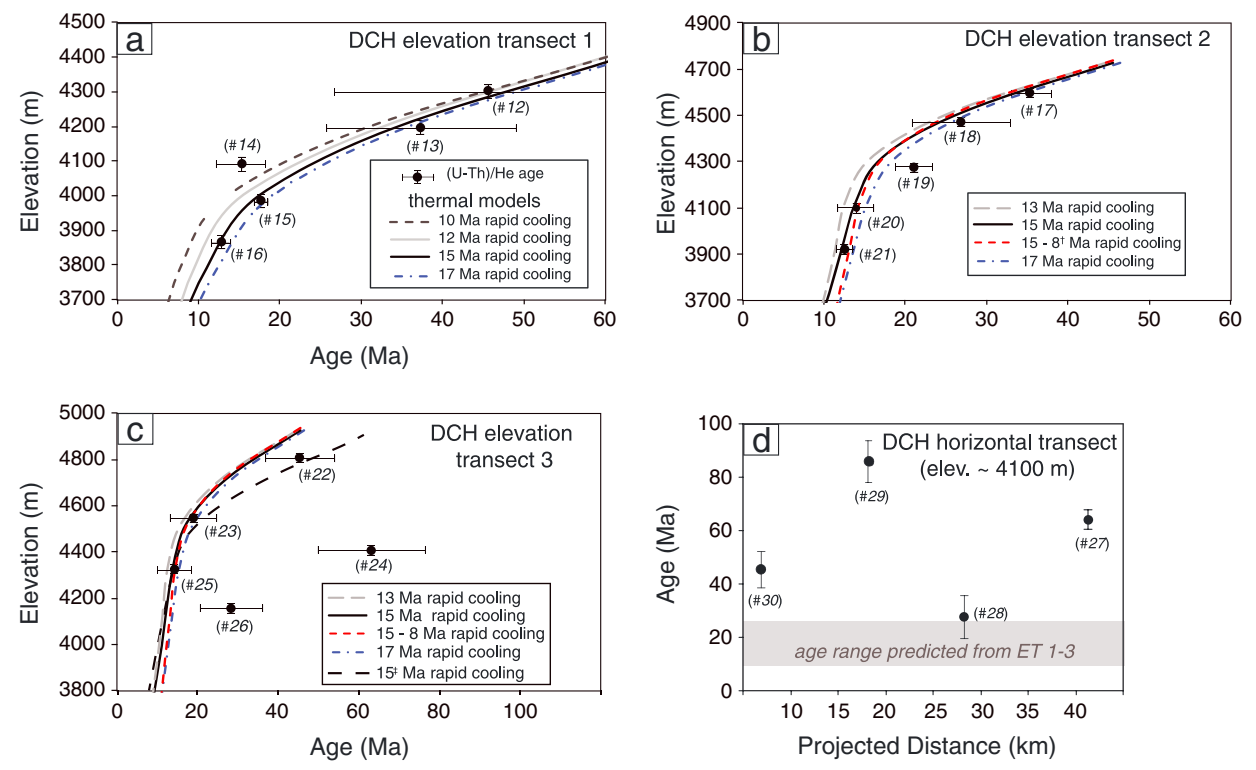

Figure 7. Helium age data for Dulan-Chaka Highland (see Figures 1 and 4 for locations). Horizontal error bars represent $2 \sigma$ uncertainty of mean age based on single-grain replicate ages from each sample and vertical error bars represent uncertainty on elevation (Tables 2 and S1). For comparison with observed data, we predicted cooling ages given various monotonic time-temperature history using a range of rapid-cooling onset times, cooling rates, and changes in rates through time using HeFTy software (see text for details). Lines show preferred model results. Timing of change to a faster cooling rate is indicated. (a) Age-elevation data, DCH elevation transect 1. (b) Age-elevation data, DCH elevation transect 2. Cooling rates must slow before the present in order to fit the data. Cooling rates decrease after $10 \mathrm{Ma}$ for the 13, 15, and $17 \mathrm{Ma}$ curves. The black dashed curve (15-8 Ma) represents a cooling history with rapid cooling beginning at $15 \mathrm{Ma}$ and abruptly terminating at $8 \mathrm{Ma}$. Abrupt and gradual decreases fit the observed data equally well. (c) Age-elevation data, DCH elevation transect 3. Cooling rate curves from ET1 and ET2 are superimposed onto the profile for comparison. We did not model ET3 data separately due to complexity of age/elevation relationship. First four curves are from ET2 and last curve (solid gray) is from ET1. (d) DCH horizontal transect. Age data plotted against projected distance (from location of DCH ET1, Figure 4). Gray band represents the range in apatite-helium age predicted for an elevation of $\sim 4100 \mathrm{~m}$ if samples along this horizontal transect experienced the same cooling history as those within the hanging wall of mapped reverse faults.

\subsubsection{Haiyuan Fault Thermochronometry Results}

[25] Sample HFC10 from the central Haiyuan Fault segment yields an apatite fission-track pooled age of $84 \pm 3 \mathrm{Ma}$ and an apatite helium age of $73 \pm 3$ Ma (Table 2). Sample HFE11 from the eastern Haiyuan Fault segment yields an apatite fission-track pooled age of $133 \pm 7 \mathrm{Ma}$ and an apatite helium age of $29 \pm 10 \mathrm{Ma}$ (Table 2). Late Cenozoic cooling events are poorly constrained by these samples. Three of these samples appear to have resided at or close to the surface since the late Cretaceous and were not reset during the Cenozoic. As a result, they are not particularly useful in assessing Cenozoic Haiyuan fault activity, though they do suggest that the region was not buried significantly ( $\geq 2 \mathrm{~km}$ ) post-Cretaceous time.

\section{Thermal Modeling}

[26] In order to further interpret the long-term thermal histories of our samples, we model time-temperature pathways using HeFTy v. 1.6.7.43 software [Ketcham, 2005] utilizing both the inverse as well as forward-modeling functions. Model results reported below correspond with simple tectonic/geomorphic scenarios most consistent with the observed age data from multiple thermochronometers (for single samples) and age/elevation data (for elevation transects). We recognize that more complicated scenarios not considered may also satisfy the data.

[27] Inverse modeling was utilized for data sets collected at single sample sites (i.e., sites without elevation transects). Model inputs included some combination of apatite fissiontrack ages and track lengths, apatite and zircon helium ages, and ${ }^{40} \mathrm{Ar} /{ }^{39} \mathrm{Ar}$ ages, depending on the data available for each site (see results section above). Apatite fission-track densities and c-axis projected track length distributions were modeled using a modification of the fanning Arrhenius model [Ketcham et al., 2007, 2009], and apatite and zircon helium data were modeled with diffusion properties of Flowers et al. [2009] and Reiners et al. [2004], respectively. In all cases, models were further constrained by surface temperatures of $10^{\circ} \mathrm{C}$. Subsegment spacing of cooling paths was allowed to vary randomly and monotonic cooling was not assumed. Models were run until 100 acceptable or good randomly generated thermal histories were found. "Acceptable" and "good" descriptors refer to a probability of worse fit designation for the thermal history envelopes calculated with a Kuiper's statistical test. These describe 
Table 3. Thermochronometry Results Summary

\begin{tabular}{lcc}
\hline Location & Sample(s) & Onset of Increased Cooling \\
\hline Kunlun Fault West & KFW1 & $30-25 \mathrm{Ma}$ \\
& KFW2 & $12-8 \mathrm{Ma}$ \\
Kunlun Fault Central & KFC3 & $20 \mathrm{Ma}$ \\
& KFC4 & $15-12 \mathrm{Ma}$ \\
Kunlun Fault East & KFE5-9 & $8-5 \mathrm{Ma}$ \\
Haiyuan Fault Central & HFC10 & - \\
Haiyuan Fault East & HFE11 & - \\
Dulan-Chaka Highland & DCH12-30 & $17-12 \mathrm{Ma}$ \\
\hline
\end{tabular}

${ }^{\mathrm{a}}$ During Cenozoic era.

the probability that were the model t-T path truly correct and the annealing and diffusion assumptions accurate, model defined ages and/or track lengths would be less similar to the model than to the data with at least $95 \%$ confidence (refer to Ketcham [2005] for further details regarding statistically significant data fits).

[28] HeFTy does not currently have a built-in function for inverting thermochronomeric data sampled along elevation transects. Instead, we estimated cooling histories of elevation transects iteratively using a suite of individual forward models designed to represent samples along a depth section. Ages were calculated by prescribing thermal histories that were identical with respect to timing, duration, magnitude, and rate of cooling but with temperature offsets between adjacent models equivalent to relative differences in depth within the rock column [Clark et al., 2010; Lease et al., 2011]. For each transect, we explored a range of rapid cooling onset times, cooling rates, and changes in rates through time to derive monotonic $\mathrm{t}-\mathrm{T}$ histories that yielded a similar shape to the observed age-elevation trends. Cooling ages were modeled using the Ketcham et al. [2007] apatite fission track model and the RDAAM apatite (U-Th)/He model [Flowers et al., 2009] and typical values for dpar and concentrations of $\mathrm{U}, \mathrm{Th}, \mathrm{Sm}$, and grain radius dimensions typical of those measured at each site (see Table S1 for specific model inputs). In order to project model-derived ages onto the age-elevation plots, we assumed a linear and invariant geothermal gradient that ranged between 25 and $30^{\circ}$ $\mathrm{C} / \mathrm{km}$ (consistent with modern geothermal gradients based on regional heat flow data [Hu et al., 2000]) and considered potential losses of overburden in order to best fit model results to the elevation range of true samples.

\subsection{Kunlun Fault Thermal Modeling Results}

[29] Cooling histories for each of the two individual KFW samples were inversely modeled using new helium ages from this study as well as ${ }^{40} \mathrm{Ar} /{ }^{39} \mathrm{Ar}$ data from Mock et al. [1999] as higher-temperature constraints. Acceptable models suggest that sample $\mathrm{KFW} 1$ underwent $\sim 170^{\circ} \mathrm{C}$ of cooling to the surface starting between 30 and $25 \mathrm{Ma}$ and lasting until 20-15 Ma, following a less well-constrained Cretaceous interval of slower cooling or isothermal holding (Figure 5a and Table 3 ). This thermal history yields cooling rates of $\sim 11-34^{\circ} \mathrm{C} / \mathrm{Myr}$ and apparent erosion rates of $\sim 0.4-1.4 \mathrm{~mm} /$ yr. In contrast, KFW2 model results suggest a younger cooling interval beginning at 12-8 Ma lasting through $\sim 5 \mathrm{Ma}$ following slow cooling or isothermal holding from at least Cretaceous time (Figure 5a and Table 3). Approximately $185^{\circ} \mathrm{C}$ of cooling during this interval yields rates of $\sim 37^{\circ} \mathrm{C} /$ Myr and apparent erosion rates of $1.2-1.5 \mathrm{~mm} / \mathrm{yr}$.
[30] Results from rocks collected along the central segment of the Kunlun Fault show $\sim 110^{\circ} \mathrm{C}$ of cooling beginning between 15 and $12 \mathrm{Ma}$ and slowing by $\sim 5 \mathrm{Ma}$ (Figure $5 \mathrm{~b}$ and Table 3) for sample KFC3, which equates to a cooling rate of $\sim 11^{\circ} \mathrm{C} / \mathrm{Myr}$ and apparent erosion rates of $\sim 0.37-0.44 \mathrm{~mm} /$ yr. In addition, a possible earlier interval of increased cooling may have begun in the Eocene. However, the rate, magnitude, and onset of such an event are poorly constrained. Model results suggest sample KFC4 underwent $\sim 110^{\circ} \mathrm{C}$ of cooling beginning at $\sim 20 \mathrm{Ma}$ and lasting through the present, which equates to a cooling rate of $5^{\circ} \mathrm{C} / \mathrm{Myr}$ and apparent erosion rates of $\sim 0.17-0.2 \mathrm{~mm} / \mathrm{yr}$. This interval of increased cooling followed a period of slower cooling or isothermal holding from at least $70 \mathrm{Ma}$ (Figure 5b and Table 3).

[31] Modeled monotonic t-T histories are compared to age results of samples collected along an elevation transect at the eastern Kunlun Fault (KFE) sample site. Except for sample KFE6, we exclude the helium ages from this modeling exercise because of poor reproducibility and incompatible ages and rely primarily on the fission-track data, which we consider to be more reliable in this case. Temperature histories prior to the onset of a prescribed erosion rate are modeled as isothermal holding, which is indistinguishable from slow erosion or slow deposition within error of the age measurements. Removal of 0.5 to $3 \mathrm{~km}$ of overburden provided fits most consistent with the observed data. A geotherm approximated as constant is likely appropriate in this setting because a combination of maximum possible erosion rates $(<1.5 \mathrm{~mm} /$ yr) and cooling duration ( $\leq 10 \mathrm{Myr})$ yields $<25 \%$ increase in thermal gradient [Ehlers, 2005].

[32] Thermal model results that reasonably define the suite of reliable ages suggest $\sim 100-170^{\circ} \mathrm{C}$ of cooling (Figure $5 \mathrm{c}$, solid and dashed lines, respectively) related to erosion of hanging wall rocks starting at 8-5 Ma after a prolonged period of isothermal holding since the Cretaceous. This range in cooling histories equates to an interval of increased cooling of $13-34^{\circ} \mathrm{C} / \mathrm{Myr}$ and apparent erosion rates of $0.4-1.4 \mathrm{~mm} / \mathrm{yr}$. For comparison, we also inversely modeled fission-track age and length data for each sample individually using HeFTy (Figure 5c, lower panels). The modeled thermal histories for samples KFE9, 8, and 7 suggest cooling $\sim 100-150^{\circ} \mathrm{C}$ beginning at 8-5 Ma (Figure 5c, lower panels), which is consistent with the preferred forward modeled cooling histories. Inverse model results for sample KFE6 suggest a thermal history with increased cooling beginning earlier at $\sim 20-15 \mathrm{Ma}$, which is an outlier to the otherwise consistent thermal histories modeled from the previous three samples. It is unclear why KFE6 would have experienced a different thermal history than the others. One possibility is that unmapped structural complexity exists along the elevation profile; however, the samples were collected with little horizontal separation $(<1 \mathrm{~km})$, which makes this scenario unlikely. No acceptable paths were found for KFE5, the highest sample on the elevation transect.

\subsection{DCH Thermal Modeling Results}

[33] Model results for elevation transects collected within the Dulan-Chaka Highland are displayed in Figure 7 (solid and dashed lines, Figures $7 \mathrm{a}-7 \mathrm{c}$ ). In all cases, geothermal gradients of $25-30^{\circ} \mathrm{C} / \mathrm{km}$ and removal of $2 \mathrm{~km}$ of overburden provided fits most consistent with the observed data. A geotherm approximated as constant is likely appropriate in this setting because a combination of maximum possible 

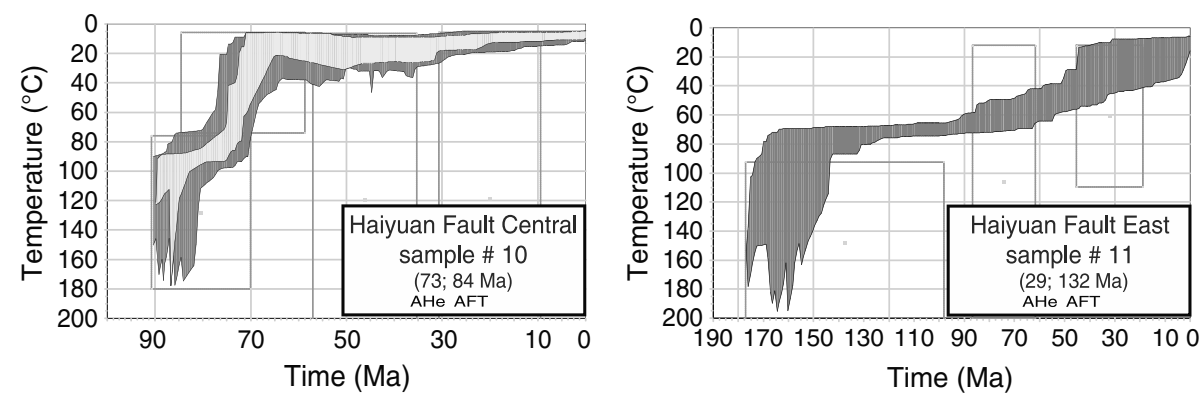

Figure 8. Thermochronometry results for the Haiyuan Fault. Two panels show results of thermal history modeling using HeFTy software for the Haiyuan Fault central (\#10) and east (\#11) locations. Swaths of time (Ma) versus temperature $\left({ }^{\circ} \mathrm{C}\right)$ represent randomly generated cooling paths that fit the data to an acceptable (dark gray) and good (light gray) standard [Ketcham, 2005] (see text for details). Models from both sites constrained by AHe (black text) and AFT (bold italic black text).

erosion rates $(<1 \mathrm{~mm} / \mathrm{yr})$ and cooling duration $(\leq 15 \mathrm{Myr})$ yields $<20 \%$ increase in thermal gradient [Ehlers, 2005].

[34] Results for ET1 (solid lines, Figure 7a) suggest $\sim 55^{\circ} \mathrm{C}$ of cooling related to erosion of hanging wall rocks starting at 15-12 Ma after a prolonged period of isothermal holding since the early Cretaceous. Our preferred models suggest increased cooling at a rate of $3.7-4.6^{\circ} \mathrm{C} / \mathrm{my}$ from $15-12 \mathrm{Ma}$ to the present representing erosion rates of $0.1-0.2 \mathrm{~mm} / \mathrm{yr}$. Results for ET2 (all curves Figure $7 \mathrm{~b}$ ) suggest $\sim 10^{\circ} \mathrm{C}$ of cooling starting at $45 \mathrm{Ma}$ following a period of isothermal holding from early Cretaceous followed by $\sim 55^{\circ} \mathrm{C}$ of cooling starting at 17-13 Ma. Unlike ET1 models, ET2 data require either an abrupt or gradual slowdown at 10-8 Ma. Preferred models suggest a modest cooling rate $\left(0.3-0.4^{\circ} \mathrm{C} / \mathrm{Myr}\right)$ between 45 and 17-13 Ma, which represents an erosion rate of $\sim 0.01 \mathrm{~mm} / \mathrm{yr}$, followed by more rapid cooling corresponding to an erosion rate up to $0.5 \mathrm{~mm} / \mathrm{yr}$ depending on whether rates abruptly decrease to zero at $8 \mathrm{Ma}$ (dashed black line, Figure $7 \mathrm{~b}$ ) or slow down gradually starting at $10-8 \mathrm{Ma}$ (solid black line and dashed gray lines, Figure 7b). We cannot discern between these erosion scenarios.

[35] ET3 age data do not exhibit a simple relationship with elevation (Figure 7c). As a result, we did not attempt to forward model this transect separately, especially without better structural context. Instead, we assess the possibility of similar cooling histories among the three profiles by importing preferred model results from ET1 and ET2 to compare with ET3 data. ET3 is generally consistent with both ET1 and ET2 (Figure 7c) though two of the samples fall off the trend within the steep part of the profile. These two older-age outliers highlight the possibility of a more complicated cooling history potentially due to greater structural complexity and nonvertical cooling pathways.

\subsection{Haiyuan Fault Thermal Modeling Results}

[36] Model results for central Haiyuan Fault sample HFC10 indicate that rocks along this segment of the fault underwent $\sim 10^{\circ} \mathrm{C}$ of cooling from $\sim 85$ to $\sim 75 \mathrm{Ma}$ and then $65^{\circ} \mathrm{C}$ of faster cooling to the surface by $\sim 70 \mathrm{Ma}$ (Figure $8 \mathrm{a}$ and Table 3 ). This model result yields a cooling rate of $13^{\circ} \mathrm{C} / \mathrm{Myr}$ and apparent erosion rates of $\sim 0.4-0.5 \mathrm{~mm} / \mathrm{yr}$. For rocks from the eastern Haiyuan Fault site, model cooling pathways record slow cooling from the Cretaceous through present, with a possible rate increase (albeit to still low rates) at $\sim 90 \mathrm{Ma}$ (Figure 8b). This cooling history suggests that the sample experienced $\sim 60^{\circ} \mathrm{C}$ of cooling in $90 \mathrm{Myr}$, which equates to a cooling rate of $0.66^{\circ} \mathrm{C} / \mathrm{Myr}$ and apparent erosion rates of $\sim 0.02-0.03 \mathrm{~mm} / \mathrm{yr}$. However, alternative cooling scenarios with short intervals of rapid cooling for small magnitude exhumation events $(<1 \mathrm{~km})$, including during the middle to late Miocene or early Pliocene, are permissible (Figure $8 \mathrm{~b}$ ).

\section{Discussion}

[37] Low-temperature cooling histories of rocks sampled along the Kunlun and Haiyuan faults provide a record of exhumation along fault traces. Based on the geologic structure and topography at each sample site, we relate exhumation to deformation and interpret periods of increased exhumation rate to constrain the timing of fault motion. Because we identify faulting by periods of exhumation, lateral motion that occurs without significant $(>1-2 \mathrm{~km})$ uplift or subsidence would go unrecorded by these methods. Thermochronometry data, therefore, have the potential to reveal the timing when a fault was active but not necessarily the timing of fault initiation.

\subsection{Kunlun Fault}

[38] Results from Kunlun samples show increased exhumation from $\sim 30$ to $20 \mathrm{Ma}$ and from circa $12-8 \mathrm{Ma}$ to present along the western fault segment, beginning circa 20-15 Ma along the central fault segment, and circa 8-5 Ma along the east fault segment. From these data, we interpret the Kunlun Fault was active by the middle to late Miocene along its entire trace and possibly earlier to the west, during the Oligocene/early Miocene.

[39] Fission-track modeling east of the central Kunlun site (Figure 1) from a previous study [Yuan et al., 2006] revealed a phase of increased cooling equating to average exhumation rates of $0.1-0.15 \mathrm{~mm} / \mathrm{yr}$ starting at $20 \mathrm{Ma}$, which is consistent with the pattern of cooling that we see from our central Kunlun Fault samples (KFC). Sample KFC4 undergoes increased cooling beginning around $20 \mathrm{Ma}$ lasting until the present and sample KFC3 shows increased cooling starting around $15 \mathrm{Ma}$ that continues until $5 \mathrm{Ma}$ (Figure 5). Mountainous terrain, including the Anyemaqen Massif, local to and aligned with the restraining bend of the Kunlun Fault lends support to the assumption that topography and exhumation result from transpression associated with left-lateral fault motion along this segment of the fault. Thus, we 
interpret the thermochronometry data to record central Kunlun faulting since at least 20-15 Ma.

[40] Interpreting the data from the western Kunlun Fault site presents a challenge due to the greater geologic complexity of the region. The western Kunlun site lies along a portion of the Kunlun fault that closely parallels a steep $2 \mathrm{~km}$ range front that separates the Qaidam Basin from the high Tibetan Plateau. Thrust faulting and range growth dominate the early Cenozoic record here [Clark et al., 2010], while thrust faulting at the range front today is inactive [Kidd and Molnar, 1988] and geodetic data suggest ENE motion dominates the modern kinematic field [Kirby et al., 2007; Duvall and Clark, 2010]. Previous thermochronometry data from steep vertical profiles in the hanging wall of the south Qaidam thrust fault $(\sim 40 \mathrm{~km}$ north of the Kunlun Fault at the range front) show an interval of rapid cooling between $\sim 35$ and $25 \mathrm{Ma}$, which is interpreted as the timing of crustal thickening and range growth (Clark et al. [2010], transect location stars in Figure 3a). To the south of our sample sites, within the Hoh Xil region of northern Tibet, thrust faulting initiated in Eocene time and continued until no later than $27 \mathrm{Ma}$ as evident from flat lying basalt flows and lake beds that rest unconformably on deformed sedimentary strata (L. M. Staisch et al., A Cretaceous-Eocene depositional age for the Fenghuoshan Group, Hoh Xil Basin Implications for the tectonic evolution of the northern Tibet Plateau, submitted to Tectonics, AGU, Washington, D. C., 2013). Although the data are sparse, we tentatively interpret that a change from crustal thickening and shortening in the NNE-SSW direction to predominant left-lateral faulting in the ENE-WNW direction occurred some time since late Oligocene and certainly by middle Miocene. However, due to the parallel nature of the Kunlun Shan thrust faults and the Kunlun strike-slip fault, no good crosscutting relationships among these structures have been identified; therefore, the exact timing of the change from thrust faulting to strike-slip is not well constrained.

[41] Although only a few kilometers apart, the two western Kunlun Fault samples from this study appear to straddle the boundary between the present trace of the Kunlun strike-slip fault and the southern extent of Kunlun Shan topography and may distinguish between the timing of strike-slip faulting versus contraction. Sample KFW2, which lies within the active Kunlun fault trace near to the junction between the Kusai Hu segment, the Xidatan-Dongdatan segment, and the Kunlun Pass Fault (Figures 1 and 2f), cooled rapidly from $\sim 12 \mathrm{Ma}$ to present (Figure 5a). In contrast, sample KFW1, which is located just north of the main Kunlun Fault strand at the edge of adjacent high topography (Figure 3a), records an earlier phase of cooling from $\sim 30$ Ma to $\sim 20$ (Figure 5a). One reasonable interpretation then is that the earlier phase of cooling recorded in sample KFW2 relates to regional reverse faulting and topographic development of the Kunlun Shan, including the $2 \mathrm{~km}$ escarpment between the Tibetan Plateau and the Qaidam Basin, and the later pulse of cooling shown by KFW1 relates to the onset of left-lateral Kunlun faulting at this location.

[42] Without independent evidence from crosscutting relationships or direct dating of brittle structures, we cannot rule out the alternative scenario that both samples reflect Kunlun strike-slip motion that occurred along this segment of the fault at $\sim 30 \mathrm{Ma}$, concurrent with or immediately following crustal thickening. Left-lateral fault motion at this time would suggest the possibility of two separate pulses of strike slip at this site (30-20 Ma and 12 Ma to present) separated by a period of inactivity lasting 5 million years or more.

[43] A late Miocene cooling event is also recorded by many of the samples from the eastern fault site. Cooling ages from the EKF elevation transect are all less than $25 \mathrm{Ma}$ and show a positive trend when plotting age versus elevation (Figure 5c). With the exception of one sample, the fission-track data indicate increased cooling at $\sim 8-5 \mathrm{Ma}$ (Figure $5 \mathrm{c}$ ). From these data, we interpret late Miocene faulting along this segment of the Kunlun Fault. We associate cooling with faulting at this site based on the observation that relief is centered along the main fault trace (Figure 3), although the specific structural relationship between topographic growth and east Kunlun strike-slip remains uncertain. In addition, late Miocene ages are concentrated near to the Kunlun Fault, whereas older, Cretaceous through early Miocene (U-Th)/He ages are documented within the surrounding area [Clark et al., 2010].

[44] Taken together, we interpret Kunlun Fault thermochronometry results to indicate horizontal motion as early as the late Oligocene locally and widespread motion along the length of the fault by Miocene time. Our results do not indicate preOligocene cooling. Although earlier left-lateral Kunlun motion cannot be ruled out from the thermochronometry data set alone, we know of no other geologic evidence, such as Eocene or older structures or basins reasonably linked to left-lateral Kunlun motion, along the studied fault segments. Moreover, left-slip motion reaching as far back as the Eocene predicts large offsets along the fault that have not been identified. Simple calculations extrapolating minimum average geodetic and Quaternary Kunlun Fault slip rates of $10 \mathrm{~mm} / \mathrm{yr}$ [Kidd and Molnar, 1988; Van der Woerd et al., 1998, 2000, 2002; Kirby et al., 2007] suggest $300 \mathrm{~km}$ of offset or greater, assuming these rates have been constant through time since a minimum of latest Eocene. Much lower documented cumulative offsets of $100 \mathrm{~km}$ or less [Kidd and Molnar, 1988; Fu and Awata, 2007] do not support early Cenozoic left-lateral activity along the Kunlun Fault as previously proposed by Jolivet et al. [2001], though admittedly, estimations of total offset are challenged by a lack of robust offset markers. Based on sample thermal histories as well as the geology of the fault zone, we favor the interpretation of a middle to late Cenozoic fault onset.

\subsection{Haiyuan Fault}

[45] Thermal histories of samples from the two Haiyuan Fault sites offer less information regarding timing of Cenozoic strike-slip faulting. Rather, sample HFC10 indicates an earlier, late Cretaceous cooling event between $\sim 85$ and $70 \mathrm{Ma}$. Cretaceous sediments are widely distributed across the northern margin of the Tibetan Plateau [Horton et al., 2004] and previous thermochronometry data from northeastern Tibet indicate $1-3 \mathrm{~km}$ of Cretaceous sediment blanketed some of the region [Clark et al., 2010]. Based on detailed geologic mapping north of the Kunlun Fault and south of the Gonghe and Linxia Basins (Figure 1), Craddock et al. [2012] argue that formation of the extensive network of Cretaceous sedimentary basins within this region relates to $\mathrm{NW}-\mathrm{SE}$ contractional deformation similar to that documented throughout the Qinling-Dabie orogen to the east [Ratschbacher et al., 2000, 2003; Enkelmann et al., 2006]. They associate this crustal shortening with a proposed step over between two parallel right-lateral shear zones and thus consider deformation to be relatively local. Other studies 


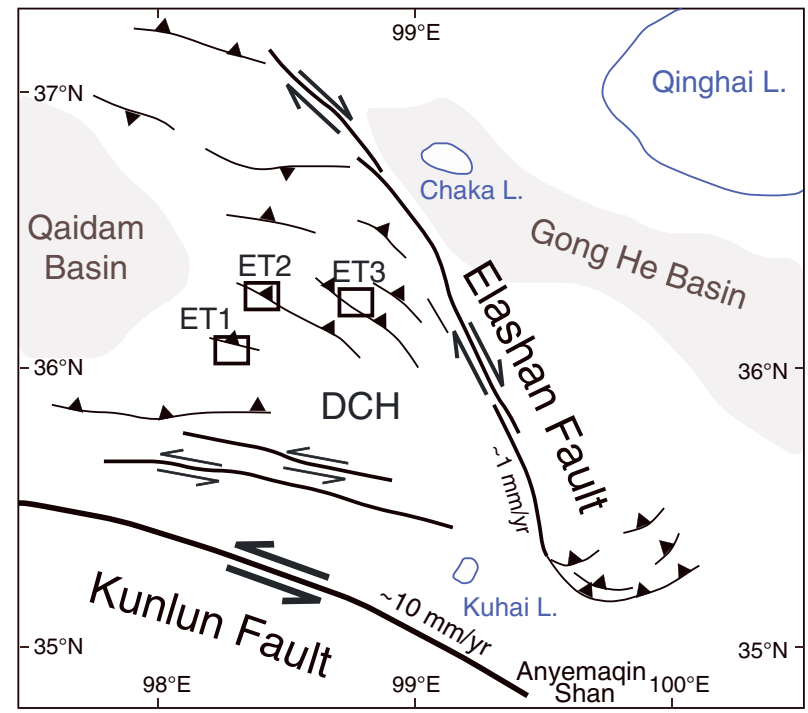

Figure 9. Line drawing highlighting the relationship between en-echelon reverse faults of the $\mathrm{DCH}$ and the Elashan and Kunlun Faults. DCH faults along with a similar but smaller zone of fanning reverse faults to the southeast comprise contractional fans along the Elashan Fault. Small extensional basins (Chaka and Kuhai lakes) also possibly accommodate strain related to right-lateral Elashan motion within the northeastern and southwestern fault corners [Wang and Burchfiel, 2004]. Figure drafted after Wang and Burchfiel, 2004.

suggest that Late Jurassic-Cretaceous sediment deposition reflects regional crustal extension and post-rift thermal subsidence [Vincent and Allen, 1999; Horton et al., 2004]. Although no direct structural relationships are observed, based on location, Cretaceous cooling recorded along the Haiyuan Fault likely relates to this proposed extensional deformation [Lin et al., 2011].

[46] Contractional deformation across the Liupan Shan beginning at 10-8 Ma [Zheng et al., 2006; Wang et al., 2011a] at the eastern termination of the Haiyuan Fault provides one of the few constraints on Cenozoic Haiyuan strike-slip timing. On the whole, sample HFE11 located $\sim 75 \mathrm{~km}$ west of the Liupan Shan (Figure 1) shows relatively slow cooling from the Cretaceous through the present. However, a late Miocene cooling event on order of $30^{\circ} \mathrm{C}$ is permitted by the acceptable modeled time-temperature paths and recently published apatite fission-track modeling results from a separate study $\sim 20 \mathrm{~km}$ to the east and $100 \mathrm{~m}$ lower elevation reveal a Miocene episode of cooling with rate increase in the late Miocene [Lin et al., 2011].

\subsection{Dulan-Chaka Highland}

[47] Deformation within the Dulan-Chaka Highland may provide at least indirect constraints on the timing of leftlateral slip along the western termination of the Haiyuan Fault. En-echelon reverse faults in the northern and central DCH fan westward from the Elashan Fault and curve to align parallel with Elashan Fault strike, possibly rooting into this structure at depth (Figure 9). Similar contractional splay faults and minor extension (Chaka and Kuhai lakes) exist on opposite corners of the fault [Wang and Burchfiel, 2004] forming a classic geometry associated with strain accommodation at the terminating ends of a right-lateral fault (Figure 9). Asymmetric DCH topography, with elevations decreasing westward into the Qaidam Basin away from a drainage divide located far to the east, in close proximity to the Elashan Fault, provides further geomorphic evidence that $\mathrm{DCH}$ deformation is associated with Elashan Fault motion. Given these observations, we agree with Wang and Burchfiel [2004] and relate Dulan-Chaka contractional faulting to right-lateral Elashan faulting. Based on the geodetic record, however, Duvall and Clark [2010] argue that the right-lateral Elashan Fault is itself an antithetic fault related to concurrent left-slip along the neighboring Kunlun and Haiyuan Faults and thus, the timing of DCH thrusting also helps to constrain the time when simultaneous west Haiyuan and central Kunlun Fault motion was ongoing.

[48] Thermochronology results from the three individual DCH elevation transects show accelerated cooling at 17-12 Ma (Figure 7), which we attribute to an increase in erosion rate following the initiation of reverse faulting. Exhumation appears to be local to fault-bounded basin and ranges as apatite helium ages of samples collected along a constant-elevation transect $(\sim 4100 \mathrm{~m})$ away from mapped faults are older than samples from similar elevations along the relief transects (Figure 7d). Variability in age among these samples (85-27 $\mathrm{Ma}$ ) hints at the potential for unmapped structures and earlier deformation in the region, though detailed mapping and additional sampling are required to further explore this possibility.

[49] Local rather than widespread cooling supports a scenario of hanging wall relief generation from faulting and subsequent erosion rather than a regional change to a more erosive climate across a landscape with significant preexisting topography $(>2.5 \mathrm{~km})$. This interpretation is further supported by climatic records within the Linxia Basin (Figure 1), which suggest a middle to late Miocene shift to more arid conditions (i.e., potentially less erosive) [Dettman et al., 2003; Fan et al., 2007]. Such a shift would suggest that tectonics rather than a more erosive climate is the cause of accelerated late Miocene cooling.

[50] Timing of 17-12 Ma DCH faulting found in this study overlaps with the Elashan Fault age determined from average Quaternary slip rates and total offset measurements $(9 \pm 3 \mathrm{Ma}$ [Yuan et al., 2011]). This timing also overlaps with the onset of deposition at circa $20 \mathrm{Ma}$ within the Gonghe basin to the east (Figure 1) [Craddock et al., 2011; Lu et al., 2012]. Erosion of the deforming DCH and Elashan region may have been a source of Gonghe sedimentation, which is supported by paleocurrent measurements from one location within the lowest strata in southern Gonghe that record eastward flow beginning after $\sim 20 \mathrm{Ma}$ [Craddock et al., 2011].

[51] Based on the timing of DCH deformation, we infer that the segments of the Kunlun and Haiyuan faults that bound this region were together active at $\sim 15 \mathrm{Ma}$. This time frame agrees well with the $20-15 \mathrm{Ma}$ increase in cooling rate found at the central Kunlun Fault sample just south of the DCH (Figure 1) but predates the 10-8 Ma deformation event in the Liupan Shan at the eastern Haiyuan fault termination [Zheng et al., 2003; Wang et al., 2011a]. A west-to-east younging in deformation associated with Haiyuan Fault activity suggests the possibility of eastern fault propagation in time. However, we consider eastward propagation to be speculative because rapid cooling events indicate fault activity, but not necessarily the initiation of faulting. 


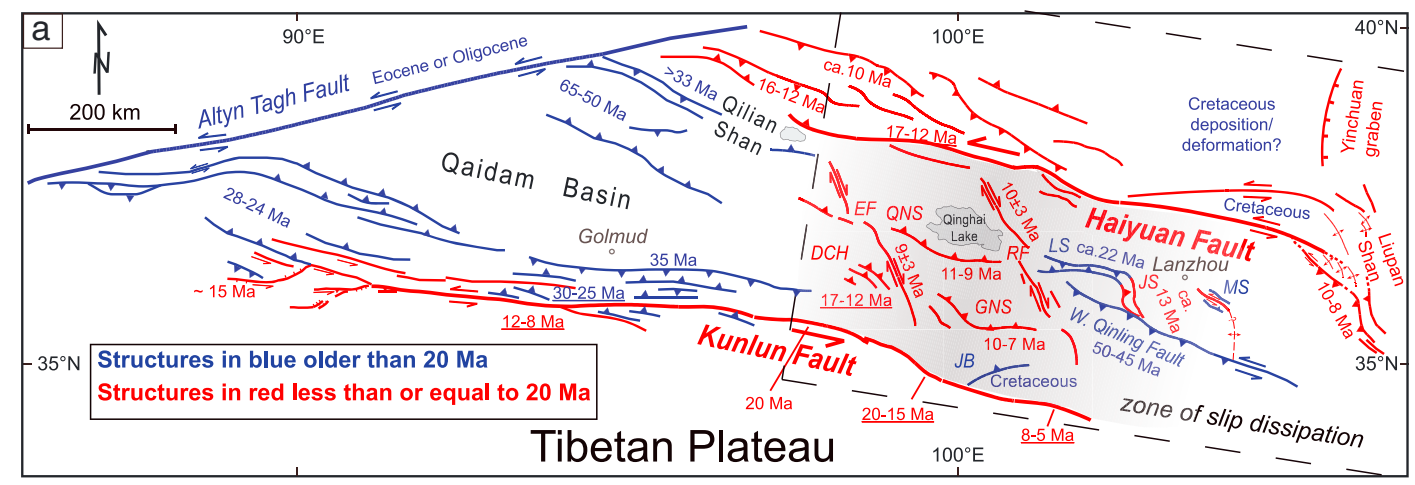

b N. Tibetan Plateau Margin Faulting through Time
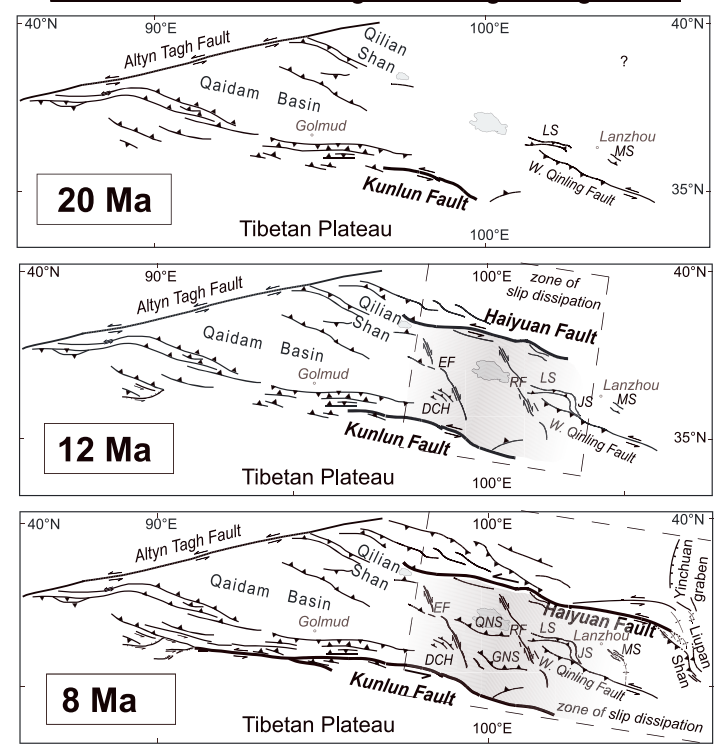

Figure 10. (a) Detailed fault map of the northern plateau margin (same extent as Figure 1). Structures in blue thought to initiate before $20 \mathrm{Ma}$, structures in red less than or equal to $20 \mathrm{Ma}$. Underscored ages are from this study, other ages compiled from previous work [Zhang et al., 1991; Mock et al., 1999; Yin et al., 2002, 2007, 2008; Jolivet et al., 2003; Zheng et al., 2003, 2006; Wang et al., 2004, Fang et al., 2005; Yuan et al., 2006; Lease et al., 2007, 2011; Bovet et al., 2009; Zheng et al., 2010; Clark et al., 2010; Duvall et al., 2011; Yuan et al., 2011; Zhang et al., 2011; Huang et al., 2011; Hough et al., 2011; Wang et al., 2011a, 2011b; Lin et al., 2011; Craddock et al., 2011]. Dark shading represents structures within the Kunlun/Haiyuan stepover region and dashed box outlines zone of Kunlun Fault left-lateral slip dissipation [Duvall and Clark, 2010]. Dulan-Chaka Highland (DCH); Elashan Fault (EF); Qinghai Nan Shan (QNS); Gong He Nan Shan (GNS); Jungong Basin (JB); Laji Shan (LS); Jishi Shan (JS); Maxian Shan (MS). (b) Proposed time steps $(20,12,8 \mathrm{Ma})$ of the late Cenozoic fault history of northeastern Tibetan Plateau margin. See text for details.

\subsection{Proposed Development of Northeastern Tibetan Plateau Margin Faulting}

[52] Synthesis of new data from this study with published results concerning many of the other structures within the northeastern Tibetan Plateau margin allows us to explore the Cenozoic structural development of region. We propose the following deformation history, which is illustrated in Figure 10 and documented in Table 4.

[53] Prior to the Miocene Epoch, the north-northeastern margin of the Tibetan Plateau was characterized primarily by contractional structures accommodating $\mathrm{N}$ or NE convergence beginning roughly at the onset of India-Eurasia collision (Eocene) [Jolivet et al., 2001; Sobel et al., 2001; Yin et al., 2002; Horton et al., 2004; Dupont-Nivet et al., 2004;
Dai et al., 2006; Yin et al., 2008a; Dayem et al., 2009; Clark et al., 2010; Duvall et al., 2011; Wang et al., 2011b; Lin et al., 2011; Huang et al., 2011]. Contraction within the eastern Kunlun Mountains and the surrounding region south of the Qaidam Basin may have been accompanied by a phase of left-lateral motion along the Kunlun Fault from 30 to 20 Ma. By approximately 20-15 Ma, we find the first evidence of Kunlun left-lateral faulting along the central segment of the fault (Figure 10b, top). Within this time frame or a few million years later, data from the DCH suggest the onset of left-lateral motion to the north, along the western Haiyuan Fault. Concurrent Kunlun and Haiyuan activity was accompanied by rotation of smaller blocks of crust $(50 \mathrm{~km} \times 50 \mathrm{~km})$ in the intervening region accommodated by right-lateral Elashan 
Table 4. Summary of Timing of Deformation From Previous Studies

\begin{tabular}{|c|c|c|}
\hline Name of Structure/Location ${ }^{\mathrm{a}}$ & Time Frame of Initiation & Publication \\
\hline Kunlun Fault strike-slip (far west) & circa $15 \mathrm{Ma}$ (possible Eocene activity) & Jolivet et al. [2003] \\
\hline Kunlun Fault strike-slip (west, south of Golmud) & $12-8 \mathrm{Ma}$ (possible activity from 30 to $20 \mathrm{Ma}$ ) & This study \\
\hline Kunlun Fault strike-slip (central) & $20-15 \mathrm{Ma}$ & Yuan et al. [2006], this study \\
\hline Kunlun Fault strike-slip (east) & $8-5 \mathrm{Ma}$ & This study \\
\hline Kunlun Mountains thrust belt (west of Golmud) & $28-24 \mathrm{Ma}$ & Jolivet et al. [2003], Yin et al. [2007] \\
\hline $\begin{array}{l}\text { Kunlun Mountains thrust belt (south and east } \\
\text { of Golmud) }\end{array}$ & $35-25 \mathrm{Ma}$ & $\begin{array}{l}\text { Mock et al. [1999], Wang et al. [2004], Clark et al. } \\
\text { [2010] }\end{array}$ \\
\hline Dulan-Chaka Highland (DCH) & $17-12 \mathrm{Ma}$ & This study \\
\hline Elashan Fault (EF) & $12-6 \mathrm{Ma}$ & Yuan et al. [2011] \\
\hline Qinghai Nan Shan (QNS) & $11-9 \mathrm{Ma}$ & Zhang et al. [2011], Craddock et al. [2011] \\
\hline Gong He Nan Shan (GNS) & $10-7 \mathrm{Ma}$ & Craddock et al. [2011] \\
\hline Jungong Basin $(\mathrm{JB})$ region & Cretaceous & Craddock et al. [2012] \\
\hline Riyueshan Fault (RF) & $13-7 \mathrm{Ma}$ & Yuan et al. [2011] \\
\hline West Qinling Fault & $50-45 \mathrm{Ma}$ & Clark et al. [2010], Duvall et al. [2011] \\
\hline Laji Shan (LS) & circa $22 \mathrm{Ma}$ & Lease et al. $[2007,2011]$ \\
\hline Jishi Shan (JS) & $13 \mathrm{Ma}$ & $\begin{array}{c}\text { Fang et al. }[2005], \text { Zheng et al. }[2006], \text { Lease et al. } \\
{[2011], \text { Hough et al. }[2011]}\end{array}$ \\
\hline Maxian Shan (MS) & Cretaceous, followed by Neogene phase & Duvall unpublished mapping \\
\hline Altyn Tagh Fault & Eocene or Oligocene & Yin et al. [2002], Ritts et al. [2008] \\
\hline Qilian Shan (south) & $65-50 \mathrm{Ma}$ & Yin et al. [2008], Huang et al. [2011] \\
\hline Qilian Shan (central) & $>33 \mathrm{Ma}$ & Yin et al. $[2002,2008]$ \\
\hline Qilian Shan (north) & $16-10 \mathrm{Ma}$ & Bovet et al. [2009], Zheng et al. [2010] \\
\hline Haiyuan Fault strike-slip (west) & $17-12 \mathrm{Ma}$ & This study \\
\hline Haiyuan Fault strike-slip (central/east)/ & $10-8 \mathrm{Ma}$ & Zheng et al. [2003], Wang et al. [2011a, 2011b], Lin \\
\hline Liupan Shan & & et al. [2011] \\
\hline North of Haiyuan Fault & Cretaceous & Zhang et al. [1991] \\
\hline
\end{tabular}

${ }^{a}$ Refer to Figure 10 for locations.

and Riyueshan antithetic faults at $13-7$ Ma [Yuan et al., 2011] and producing regional transpression and crustal thickening along ENE striking thrust and reverse fault-bounded mountain ranges starting at $\sim 15 \mathrm{Ma}$ in the Dulan-Chaka Highland, $\sim 11 \mathrm{Ma}$ in the Ela Shan [Zhang et al., 2011], $\sim 10-7 \mathrm{Ma}$ in the Gonghe Nan Shan [Craddock et al., 2011], and $\sim 6 \mathrm{Ma}$ in the Qinghai Nan Shan [Zhang et al., 2011]. East of the Riyueshan Fault, formation of the N-S oriented Jishi thrust fault and associated basin sedimentation began at $\sim 13$ Ma [Zheng et al., 2003; Fang et al., 2005; Lease et al., 2011; Hough et al., 2011]. By 12-8 Ma, Kunlun faulting either began or was renewed along the western segment (Figure 10b, middle), followed by left-lateral faulting along the eastern segments of the Kunlun and Haiyuan Faults, concurrent with increased deformation within the greater Anyemaqin region of high topography, the Liupan Shan region of thrusts and folds [Zheng et al., 2006; Wang et al., 2011a; Lin et al., 2011], and the adjacent Tianshui Basin to the southeast [Wang et al., 2011b] (Figure 10b, bottom).

[54] This collective history shows that much of the faulting, range growth, and basin deposition along many of the smaller structures (50-100 km in length) of northeastern Tibet were commensurate with or postdate the earliest evidence of slip along the bounding Kunlun and Haiyuan Faults (Figure 10a). Both timing and modern strain patterns from geodetic data [Duvall and Clark, 2010] support that deformation in this region is associated with a broad step over zone between the Kunlun and Haiyuan faults (Figure 10).

\subsection{Geodynamic Implications}

[55] The deformation events of the interior northeastern plateau margin suggest a transition from an earlier phase of $\mathrm{N}$ NNE directed thrust faulting to a phase of transpression with the development of the Kunlun and Haiyuan fault system during middle Miocene time. The growth history of strike-slip and associated deformation that we propose here spans 15 million years or more and results in a more complicated pattern of faults and folding than was present during the earlier EoceneOligocene period of deformation after India-Asia collision (Figure 10). The timing of the development of the KunlunHaiyuan strike-slip system also coincides with a proposed transition beginning in the early middle Miocene (circa

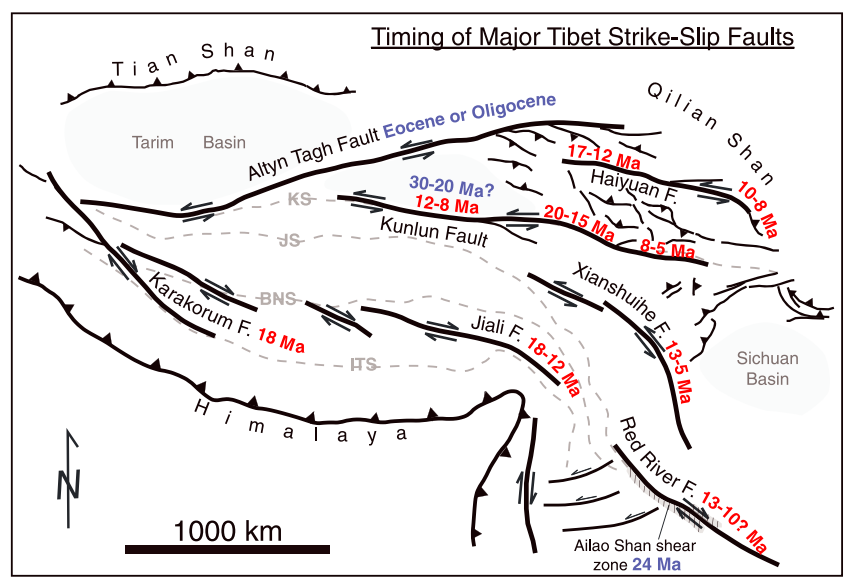

Figure 11. Simplified geologic map showing major strikeslip faults of the Tibetan Plateau [after Taylor and Yin, 2009; Schoenbohm et al., 2006] as well as compressive structures of the northern Tibetan Plateau margin. Faults estimated to initiate pre-Miocene shown in blue and Miocene and younger shown in red. Tibetan Plateau suture boundaries shown by dashed gray lines: ITS Indus-Tsangpo suture, BNS Bangong Nujiang suture, JS Jinsha suture, KS Kunlun suture. Age brackets represent the timing of onset of strikeslip motion (from compilation of ages in Searle et al. [2011] and this study). 
18-15 Ma) from an "extrusion phase" along the Altyn Tagh Fault accommodated by fast slip ( $>20 \mathrm{~mm} / \mathrm{yr}$ ) to mainly surface uplift and shortening in the Altun Shan [Yue et al., 2004; Ritts et al., 2008; Kent-Corson et al., 2009] and the wider Qilian Shan region [Zheng et al., 2010; Huang et al., 2011].

[56] Ages of the Kunlun and Haiyuan Faults from this study overlap with the ages of several of the other major intracontinental strike-slip faults of the Tibetan Plateau, which implies a regional rather than local driving force. With exception to the Altyn Tagh Fault and the Ailao Shan shear zone, which initiated earlier, major strike-slip fault motion appears to begin within the span of time from $\sim 20$ to 5 Ma (Figure 11) [Searle et al., 2011]. The oldest (Kunlun and Karakorum) and youngest (Xianshuihe) faults possibly vary by as much as 15 million years, though we cannot discern whether this reflects true variability in onset age or is a function of limited data resolution. In any case, the time frame of widespread strike-slip faulting within the interior Tibetan Plateau is late in the orogen's history.

[57] Similarity in timing of late-stage strike-slip faulting of Tibet with mid-to-late Miocene initiation of major river incision within the easternmost margin of Tibet [Clark et al., 2005; Ouimet et al., 2010; Wilson and Fowler, 2011; Duvall et al., 2012] and to the proposed timing of plateau expansion associated with various processes such as lower crustal flow to the north and east [Clark and Royden, 2000; Kirby et al., 2002; Clark et al., 2006; Royden et al., 1997, 2008; Cook and Royden, 2008; Ouimet et al., 2010], loss of mantle lithosphere, northern plateau rise, and marginal deformation [Molnar et al., 1993; Molnar and Stock, 2009], and stepwise plateau growth through intracontinental mantle subduction [Meyer et al., 1998; Tapponnier et al., 2001] suggests potential links among some or all of these processes.

[58] Deformation along the northern margin of the Tibetan Plateau appears to propagate only a small amount northward and eastward $(<200 \mathrm{~km})$, therefore the northern plateau margin has remained rather stationary as the Indian continent moves northward into the plateau [Clark et al., 2010; Duvall et al., 2011; Clark, 2012, Duvall et al., 2012]. The progressive thickening of Tibetan crust coupled with confinement against rigid crustal blocks to the north [Kong et al., 1997; Dayem et al., 2009; Clark, 2012] may have impeded northward growth of the plateau, ultimately leading to the change from thrust-faulting to late stage widespread lateral strain in the upper crust and eastward expansion. Late-stage strike-slip faulting related to progressive crustal thickening has also been indicated in other continental convergence zones such as the Carpathians and the Dinarides-Hellenides [e.g., Nemcok, 1993; Pincha, 2002, 2011]. Thus, margin-parallel deformation may be a regular development in maturing convergent orogens.

\section{Conclusions}

[59] This work provides new constraints on the timing of the Kunlun and Haiyuan left-lateral faults by low-temperature thermochronometry in samples collected along and adjacent to the main fault strands and from new mapping and thermochronometry from the Dulan-Chaka Highland, which sits in between the bounding Kunlun and Haiyuan Faults. Data from three separate locations along strike of the Kunlun Fault show periods of increased cooling at $\sim 30-25$ and
12-8 Ma along the western segment, at $20-15$ Ma along the central segment, and at $\sim 8-5 \mathrm{Ma}$ along the eastern segment. Data from two sites along the Haiyuan Fault record mainly Cretaceous cooling that we interpret to predate onset of strike-slip faulting. Results from the Dulan-Chaka Highland support the initiation of contraction and right-lateral shear within this region at $\sim 15 \mathrm{Ma}$. We interpret cooling of our samples to relate to exhumation during deformation events linked to strike-slip faulting and suggest that major left-lateral faulting was ongoing by the middle to late Miocene along the lengths of the Kunlun and Haiyuan Faults, and potentially beginning earlier, during the late Oligocene or early Miocene, along the western Kunlun Fault segment.

[60] Based on the timing and geometries of many of the other structures within northeastern Tibet, we suggest that Kunlun and Haiyuan Fault activity played a primary role in the Miocene-Pliocene evolution of the structural landscape within this region, overprinting an earlier history of thrust faulting that initiated near the timing of Indo-Asia collision. Miocene onset of Kunlun and Haiyuan left-lateral faulting is also consistent with initiation ages of other major intracontinental strike-slip faults within the plateau and may be an expected late-stage development in continental crust due to long-term plate convergence.

[61] Acknowledgments. This work was supported by the NSF (grants EAR-0507431, EAR-0507788, EAR-0908711), the National Science Foundation of China (40234040), and by the State Key Laboratory of Earthquake Dynamics (LED2008A01). We thank Lindsay Hedges for assistance with sample analyses, and Nathan Harkins, Xuhua Shi, Katherine Dayem, Karen Lease, colleagues at the Lanzhou Institute of Seismology, Pei-Zhen Zhang and colleagues at the State Key Laboratory of Earthquake Dynamics, Institute of Geology, China Earthquake Administration for help with sample collection and field support. We also thank anonymous reviewers for thorough and instructive feedback that greatly improved the paper. We also acknowledge Nathan Niemi, Douglas Burbank, Zheng Dewen, and Peter Molnar for constructive dialogue regarding this work.

\section{References}

Allen, M., J. Jackson, and R. Walker (2004), Late Cenozoic reorganization of the Arabia-Eurasia collision and the comparison of short-term and long-term deformation rates, Tectonics, 23, TC2008, doi:10.1029/ 2003TC001530

Armijo, R., P. Tapponnier, J. L. Mercier, and H. Tong-Lin (1986), Quaternary extension in southern Tibet: Field observations and tectonic implications, J. Geophys. Res., 91, 13,803-13,813.

Armijo, R., P. Tapponnier, and H. Tonglin (1989), Late Cenozoic right-lateral strike-slip faulting in southern Tibet, J. Geophys. Res., 94, 2787-2838.

Aydin, A., and A. Nur (1985), The types and role of stepovers in strike-slip tectonics, in Strike-Slip Deformation, Basin Formation, and Sedimentation, Spec. Publ. Soc. Econ. Paleontol. Mineral. vol. 37, edited by K. T. Biddle and N. Christie-Blick, pp. 35-44.

Bally, A., T. Ryder, and H. Euster (1986), Comments on the geology of the Qaidam basin: Notes on sedimentary basins in China-Report of the American Sedimentary Basins Delegation to the People's Republic of China, U.S. Geological Survey Open-File Report, p. 86-327.

Batt, G. E., and J. Braun (1999), The tectonic evolution of the Southern Alps, New Zealand: insights from fully thermally coupled dynamical modeling, Geophys. J. Int., 136, 403-420.

Benowitz, J. P., P. Layer, S. Armstrong, S. Perry, P. Haeussler, P. Fitzgerald, and S. Van Laningham (2011), Spatial variations in focused exhumation along a continental-scale strike-slip fault: The Denali Fault of Eastern Alaska Range, Geosphere, 7, 455-467.

Biddle, K. T., and N. Christie-Blick (Eds) (1985), Strike-Slip Deformation, Basin Formation, and Sedimentation, Spec. Publ. Soc. Econ. Paleontol. Mineral., 37, pp. 356.

Bilham, R., and G. King (1989), The morphology of strike-slip faultsExamples from the San Andreas Fault, California, J. Geophys. Res., 94, 10,204-10,216.

Bird, P. (1991), Lateral extrusion of lower crust from under high topography in the isostatic limit, J. Geophys. Res., 96, 10,275-10,286. 
Blisniuk, P. M., B. R. Hacker, B. R. Glodny, L. Ratschbacher, S. Bi, Z. Wu, M. O. McWilliams, and A. Calvert (2001), Normal faulting in central Tibet since at least $13.5 \mathrm{Myr}$ ago, Nature, 412, 628-632.

Bovet, P. M., B. D. Ritts, G. Gehrels, A. O. Abbink, B. Darby, and J. Hourigan (2009), Evidence of Miocene crustal shortening in the north Qilian Shan from Cenozoic stratigraphy of the western Hexi Corridor, Gansu Province, China, Am. J. Sci., 309, 290-329.

Burke, K., and C. Sengor (1986), Tectonic escape in the evolution of the continental crust, Geodynamics Series, 14, 41-53.

Cavalié, O., C. Lasserre, M. P. Doin, G. Peltzer, J. Sun, X. Xu, and Z. K. Shen (2008), Measurement of interseismic strain across the Haiyuan fault (Gansu, China), by InSAR, Earth Planet. Sci. Lett., 275, 246-257.

Chinnery, M. A. (1965), The vertical displacements associated with transcurrent faulting, J. Geophys. Res., 70, doi:10.1029/JZ070;018p04627.

Christie-Blick, N., and K. T. Biddle (1985), Deformation and basin formation along strike-slip faults, in Strike-Slip Deformation, Basin Formation, and Sedimentation, Society of Economic Paleontologists and Mineralogists Special Publication No. 37, edited by K. T. Biddle and N. Christie-Blick, pp. 1-34.

Clark, M. K. (2012), Continental collision slowing due to viscous mantle lithosphere rather than topography, Nature, 483, 74-77, doi:10.1038/ nature10848.

Clark, M. K., and L. H. Royden (2000), Topographic ooze: Building the eastern margin of Tibet by lower crustal flow, Geology, 28(8), 703-706.

Clark, M. K., M. A. House, L. H. Royden, K. X. Whipple, B. C. Burchfiel, X. Zhang, and W. Tang (2005), Late Cenozoic uplift of southeastern Tibet, Geology, 33(6), 525-528, doi:10.1130/G21265.1

Clark, M. K., L. H. Royden, K. X. Whipple, B. C. Burchfiel, X. Zhang, and W. Tang (2006), Use of a regional, relict landscape to measure vertical deformation of the eastern Tibetan Plateau, J. Geophys. Res., 111, F03002, doi:10.1029/2005JF000294.

Clark, M. K., K. A. Farley, D. W. Zheng, Z. C. Wang, and A. R. Duvall (2010), Early Cenozoic faulting of the northern Tibetan Plateau margin from apatite (U-Th)/He ages, Earth Planet. Sci. Lett., 296, 78-88.

Coney, P. J., and T. A. Harms (1984), Cordilleran metamorphic core complexes: Cenozoic extensional relics of Mesozoic compression, Geology, $12,550-554$.

Cook, K. L., and L. H. Royden (2008), The role of crustal strength variations in shaping orogenic plateaus, with application to Tibet, J. Geophys. Res., 113, B08407, doi:10.1029/2007JB005457.

Copley, A., and J. Jackson (2006), Active tectonics of the Turkish-Iranian Plateau, Tectonics, 25, TC6006, doi:10.1029/2005TC001906.

Cowgill, E. (2007), Impact of riser reconstructions on estimation of secular variation in rates of strike-slip faulting: Revisiting the Cherchen River site along the Altyn Tagh Fault, NW China, Earth Planet. Sci. Lett., 254, 239-255.

Craddock, W. H., E. Kirby, and H. Zhang (2011), Late Miocene-Pliocene range growth in the interior of the northeastern Tibetan Plateau, Lithosphere, 3(6), doi:10.1130/L159.1.

Craddock, W. H., E. Kirby, D. Zheng, and J. Liu (2012), Tectonic setting of Cretaceous basins on the NE Tibetan Plateau: Insights from the Jungong basin, Basin Res., 24(1), 51-69, doi:10.1111/ j.1365.2117.2011.00515.x.

Crowell, J. C. (1974), Origin of late Cenozoic basins in southern California, in tectonics and sedimentation, Soc. Econ. Paleontologists and Mineralogists Spec. Pub. 22, p. 190-204.

Dai, S., X. M. Fang, G. Dupont-Nivet, C. H. Song, J. P. Gao, W. Krijgsman, C. Langereis, and W. L. Zhang (2006), Magnetostratigraphy of Cenozoic sediments from the Xining Basin: Tectonic implications for the northeastern Tibetan Plateau, J. Geophys. Res., 111, B11102, doi:10.1029/2005JB004187.

Dayem, K. E., P. Molnar, M. K. Clark, and G. A. Houseman (2009), Farfield lithospheric deformation in Tibet during continental collision, Tectonics, 28, TC6005, doi:10.1029/2008TC002344.

Dettman, D. L., X. Fang, C. N. Garzione, and J. Li (2003), Uplift-driven climate change at $12 \mathrm{Ma}$ : A long $\delta^{18} \mathrm{O}$ record from the NE margin of the Tibetan Plateau, Earth Planet. Sci. Lett., 214, 267-277.

Donelick, R. A., P. B. O'Sullivan, and R. A. Ketcham (2005), Apatite fission-track analysis, Rev. Mineral. Geochem., 58, 49-94.

Dupont-Nivet, G., B. K. Horton, R. F. Butler, J. Wang, J. Zhou, and G. L. Waanders (2004), Paleogene clockwise tectonic rotation of the Xining-Lanzhou region, northeastern Tibetan Plateau, J. Geophys. Res., 109, B04401, doi:10.1029/2003JB002620.

Duvall, A. R., and M. K. Clark (2010), Dissipation of fast strike-slip faulting within and beyond northeastern Tibet, Geology, 38, 223-226.

Duvall, A. R., M. K. Clark, B. A. van der Pluijm, and C. Li (2011), Direct dating of Eocene reverse faulting in northeastern Tibet using Ar-dating of fault clays and low-temperature thermochronometry, Earth Planet. Sci. Lett., 304(3-4), 520-526.
Duvall, A. R., M. K. Clark, B. Avdeev, K. A. Farley, and Z. Chen (2012), Widespread late Cenozoic increase in erosion rates across the interior of eastern Tibet constrained by detrital low-temperature thermochronometry, Tectonics, 31, TC3014, doi:10.1029/2011TC002969.

Ehlers, T. A. (2005), Crustal thermal properties and thermchronometer data interpretation, in Low-Temperature Thermochonology: Techniques, Interpretations, and Applications, Rev. Mineral. Geochem., 58, edited by P. W. Reiners, and T. A. Ehlers, pp. 315-350, Mineralogical Society of America, Chantilly, VA.

Ehlers, T. A., and K. A. Farley (2003), Apatite (U-Th)/He thermochronometry: Methods and applications to problems in tectonic and surface processes, Earth Planet. Sci. Lett., 206, 1-14.

England, P., and G. Houseman (1989), Extension during continental convergence, with application to the Tibetan Plateau, J. Geophys. Res., 94, 17,561-17,579.

Enkelmann, E., L. Ratschbacher, R. Jonckheere, R. Nestler, M. Fleischer, R. Gloaguen, B. R. Hacker, Y. Q. Zhang, and Y. S. Ma (2006), Cenozoic exhumation and deformation of northeastern Tibet and the Qinling: Is Tibetan lower crustal flow diverging around the Sichuan Basin?, Geol. Soc. Am. Bull., 118(5-6), 651-671.

Fan, M., D. L. Dettman, C. Song, X. Fang, and C. N. Garzione (2007), Climatic variation in the Linxia basin, NE Tibetan Plateau, from 13.1 to 4.3 Ma: The stable isotope record, Palaeogeogr. Palaeoclimatol. Palaeoecol., 247, 313-328.

Fang, X., M. Yan, R. Van der Voo, D. K. Rea, C. Song, J. M. Parés, J. Gao, J. Nie , and S. Dai (2005), Late Cenozoic deformation and uplift of the NE Tibetan Plateau: Evidence from high-resolution magnetostratigraphy of the Guide Basin, Qinghai Province, China, Geol. Soc. Am. Bull., 117, 1208-1225.

Farley, K. (2000), Helium diffusion from apatite: General behavior as illustrated by Durango fluorapatite, J. Geophys. Res., 105, 2903-2914.

Farley, K. A., and D. F. Stockli (2002), (U-Th)/He dating of phosphates: Apatite, monazite, and xenotime, in Phosphates: Geochemical, Geobiological, and Materials Importance: Reviews in Mineralogy \& Geochemistry, edited by M. J. Kohn, J. Rakovan, and J. M. Hughes, pp. 559-577, Mineralogical Society of America, Chantilly, VA.

Farley, K. A., D. A. Shuster, and R. A. Ketcham (2011), U and Th zonation in apatite observed by laster ablation ICPMS, and implications for the (U-Th)/He system, Geochim. Cosmochim. Acta, 75, 4515-4530.

Fitch, T. J. (1972), Plate convergence, transcurrent faults, and internal deformation adjacent to Southeast Asia and the western Pacific, J. Geophys. Res., 77(23), 4432-4460.

Fitzgerald, P. G., and A. J. W. Gleadow (1990), New Approaches in FissionTrack Geochronology as a Tectonic Tool - Examples from the Transantarctic Mountains, Nucl. Tracks Radiat. Meas., 17, 351-357.

Flowers, R. M., R. A. Ketcham, D. L. Shuster, and K. A. Farley (2009), Apatite (U-Th)/He thermochronometry using a radiation damage accumulation and annealing model, Geochim. Cosmochim. Acta, 73, 2347-2365.

$\mathrm{Fu}, \mathrm{B}$. H., and Y. Awata (2007), Displacement and timing of left-lateral faulting in the Kunlun Fault Zone, northern Tibet, inferred from geologic and geomorphic features, J. Asian Earth Sci., 29, 253-265.

Galbraith, R. F., and G. M. Laslett (1993), Statistical models for mixed fission track ages, Nucl. Tracks Radiat. Meas., 21, 459-470.

Gallagher, K., R. Brown, and C. Johnson (1998), Fission track analysis and its applications to geological problems, Ann. Rev. Earth Planet. Sci., 26, 519-572. Gansu Bureau Geological and Mineral Resources (BGMR) Gansu Province (1989), Regional Geology of Gansu Province, Geological Publishing House, Beijing (in Chinese), $690 \mathrm{p}$.

Gaudemer, Y., P. Tapponnier, B. Meyer, G. Peltzer, S. M. Guo, Z. T. Chen, H. G. Dai, and I. Cifuentes (1995), Partitioning of crustal slip between linked, active faults in the eastern Qilian Shan, and evidence for a major seismic gap, the Tianzhu Gap, on the western Haiyuan Fault, Gansu (China), Geophys. J. Int., 120, 599-645.

Gemmer, L., and G. A. Houseman (2007), Convergence and extension driven by lithospheric gravitational instability: Evolution of the AlpineCarpathian-Pannonian system, Geophys. J. Int., 168, 1276-1290.

Gleadow, A., and I. Duddy (1981), A natural long-term track annealing experiment for apatite, Nucl. Tracks, 5, 169-174.

Harkins, N., E. Kirby, A. Heimsath, R. Robinson, and U. Reiser (2007), Transient fluvial incision in the headwaters of the Yellow River, northeastern Tibet, China, J. Geophys. Res., 112, F03S04, doi:10.1029/2006JF000570.

Harkins, N., and E. Kirby (2008), Fluvial terrace riser degradation and determination of slip rates on strike-slip faults: An example from the Kunlun fault, China, Geophys. Res. Lett., 35, L05406, doi:10.1029/2007GL033073.

Harkins, N., E. Kirby, X. Shi, E. Wang, D. Burbank, and F. Chun (2010), Millennial slip rates along the eastern Kunlun fault: Implications for the dynamics of intracontinental deformation in Eurasia, Lithosphere, 2, 247-266.

Horton, B. K., G. Dupont-Nivet, J. Zhou, G. L. Waanders, R. F. Butler, and J. Wang (2004), Mesozoic-Cenozoic evolution of the Xining-Minhe and Dangchang basins, northeastern Tibetan Plateau: Magnetostratigraphic and biostratigraphic results, J. Geophys. Res., 109, B04402, doi:10.1029/ 2003JB002913. 
Hough, B. G., C. N. Garzione, Z. Wang, R. O. Lease, D. W. Burbank, and D. Yuan (2011), Stable isotope evidence for topographic growth and basin segmentation: Implications for the evolution of the NE Tibetan Plateau, Bull. Geol. Soc. Am., 123, 168-185.

Hu, S., L. He, and J. Wang (2000), Heat flow in the continental area of China: A new data set, Earth Planet. Sci. Lett., 179(2), 407-419.

Huang, G., J. K. Hourigan, B. Z. Ritts, and M. L. Kent-Corson (2011), Cenozoic multiple-phase tectonic evolution of the northern Tibetan Plateau: Constaints from sedimentary records from Qaidam Basin, Hexi Corridor, and Subei Basin, northwest China, Am. J. Sci., 311, 116-152.

Jolivet, M., M. Brunel, D. Seward, Z. Xu, J. Yang, F. Roger, P. Tapponnier, J. Malavieille, N. Arnaud, and C. Wu (2001), Mesozoic and Cenozoic tectonics of the northern edge of the Tibetan plateau: Fission-track constraints, Tectonophysics, 343, 111-134.

Jolivet, M., M. Brunel, D. Seward, Z. Xu, J. Yang, J. Malavieille, F. Roger, A. Leyreloup, N. Arnaud, and C. Wu (2003), Neogene extension and volcanism in the Kunlun Fault Zone, northern Tibet: New constraints on the age of the Kunlun Fault, Tectonics, 22(5), 1052, doi:10.1029/2002TC001428.

Jones, C. H., J. R. Unruh, and L. J. Songer (1996), The role of gravitational potential energy in active deformation in the southwestern United States, Nature, 381, 37-41.

Kent-Corson, M. L., B. D. Ritts, G. Zhuang, P. M. Bovet, S. Graham, and C. P. Chamberlain (2009), Stable isotope constraints on the tectonic, topographic, and climatic-evolution of the northern margin of the Tibetan Plateau, Earth Planet. Sci. Lett., 282, 158-166.

Ketcham, R. A. (2005), Forward and inverse modeling of low-temperature thermochronometry data, Rev. Mineral. Geochem., 58, 275-314.

Ketcham, R. A., A. Carter, R. A. Donelick, J. Barbarand, and A. J. Hurford (2007), Improved modeling of fission-track annealing in apatite, $\mathrm{Am}$. Mineral., 92, 799-810.

Ketcham, R. A., R. A. Donelick, M. L. Balestrieri, and M. Zattin (2009), Reproducibility of apatite fission-track length data and thermal history reconstruction, Earth Planet. Sci. Lett., 284, 504-515.

Kidd, W. S. F., and P. Molnar (1988), Quaternary and active faulting observed on the 1985 Academia Sinica-Royal Society Geotraverse of Tibet, Phil. Trans. Roy. Soc. Lond. Math. Phys. Sci., 327, 337-363.

Kirby, E., P. W. Reiners, M. A. Krol, K. X. Whipple, K. V. Hodges, K. A. Farley, W. Q. Tang, and Z. L. Chen (2002), Late Cenozoic evolution of the eastern margin of the Tibetan Plateau: Inferences from Ar-40/Ar-39 and (U-Th)/He thermochronology, Tectonics, 21(1), 1001, doi:10.1029/ 2000 TC001246.

Kirby, E., N. Harkins, E. Q. Wang, X. H. Shi, C. Fan, and D. Burbank (2007), Slip rate gradients along the eastern Kunlun fault, Tectonics, 26, TC2010, doi:10.1029/2006TC002033.

Kirby, E., and N. Harkins (2013), Distributed deformation around the eastern tip of the Kunlun fault, Int. J. Earth Sci., 35, doi:10.1007/s..531-013-0872-x.

Kong, X., A. Yin, and T. M. Harrison (1997), Evaluating the role of preexisting weaknesses and topographic distributions in the Indo-Asian collision by use of a thin-shell numerical model, Geology, 25(6), 527-530.

Lasserre, C., et al. (1999), Postglacial left slip rate and past occurrence of M $>=8$ earthquakes on the western Haiyuan fault, Gansu, China, J. Geophys. Res., 104, 17,633-17,651.

Lasserre, C., Y. Gaudemer, P. Tapponnier, A. S. Meriaux, J. Van der Woerd, D. Y. Yuan, F. J. Ryerson, R. C. Finkel, and M. W. Caffee (2002), Fast late Pleistocene slip rate on the Leng Long Ling segment of the Haiyuan fault, Qinghai, China, J. Geophys. Res., 107(B11), 2276, doi:10.1029/ $2000 J B 000060$.

Lease, R. O., D. W. Burbank, G. E. Gehrels, Z. C. Wang, and D. Y. Yuan (2007), Signatures of mountain building: Detrital zircon U/Pb ages from northeastern Tibet, Geology, 35, 239-242.

Lease, R. O., D. W. Burbank, M. K. Clark, K. A. Farley, D. Zheng, and H. Zhang (2011), Middle Miocene reorganization of deformation along the northeastern Tibetan Plateau, Geology, 39, 359-362.

Li, C. Y., P. Z. Zhang, J. H. Yin, and W. Min (2009), Late Quaternary leftlateral slip rate of the Haiyuan fault, northeastern margin of the Tibetan Plateau, Tectonics, 28, TC5010, doi:10.1029/2008TC002302.

Lin, X., H. Chen, K. H. Wyrwoll, G. E. Batt, L. Liao, and J. Xiao (2011), The Uplift History of the Haiyuan-Liupan Shan region northeast of the present Tibetan Plateau: Integrated constraint from stratigraphy and thermochronology, J. Geol., 119(4), 372-393.

Lu, H., E. Wang, X. Shi, and K. Meng (2012), Cenozoic tectonic evolution of the Elashan range and its surroundings, northern Tibetan Plateau as constrained by paleomagnetism and apatite fission track analyses, Tectonophysics, 580, 150-161.

McClay, K., and M. Bonora (2001), Analog models of restraining stepovers in strike-slip fault systems, AAPG Bulletin, 85(2), 233-260.

Mercier, J.-L., R. Armijo, P. Tapponnier, E. Carey-Gailhardis, and H. Tong Lin (1987), Change from Late Tertiary compression to Quaternary extension in southern Tibet during the India-Asia collision, Tectonics, 6, 275-304.
Meyer, B., P. Tapponnier, L. Bourjot, F. Metivier, Y. Gaudemer, G. Peltzer, G. Shunmin, and C. Zhitai (1998), Crustal thickening in Gansu-Qinghai, lithospheric mantle subduction, and oblique, strike-slip controlled growth of the Tibet plateau, Geophys. J. Int., 135, 1-47.

Mock, C., N. O. Arnaud, and J. M. Cantagrel (1999), An early unroofing in northeastern Tibet? Constraints from Ar-40/Ar-39 thermochronology on granitoids from the eastern Kunlun range (Qianghai, NW China), Earth Planet. Sci. Lett., 171, 107-122.

Molnar, P., and J. M. Stock (2009), Slowing of India's convergence with Eurasia since $20 \mathrm{Ma}$ and its implications for Tibetan mantle dynamics, Tectonics, 28, TC3001, doi:10.1029/2008TC002271.

Molnar, P., and P. Tapponnier (1975), Cenozoic tectonics of Asia: Effects of a continental collision, Science, 189, 419-426.

Molnar, P., P. England, and J. Martinod (1993), Mantle dynamics, uplift of the Tibeatan Plateau, and the Indian monsoon, Rev. Geophys., 31, 357-396.

Nemcok, M. (1993), Transition from convergent escape: Field evidence from the West Carpathians, Tectonophysics, 217(1-2), 117-142.

Ouimet, W., K. Whipple, L. Royden, P. Reiners, K. Hodges, and M. Pringle (2010), Regional incision of the eastern margin of the Tibetan Plateau, Lithosphere, 2(1), 50-63.

Pan, G., J. Ding, D. Yao, and L. Wang (2004), Guidebook of 1:1,500,000 Geologic Map of the Qinghai-Xizang (Tibet) Plateau and Adjacent Areas, Chengdu Cartographic Publishing House, Chengdu, China, pp. 48.

Pincha, F. J. (2002), Late orogenic strike-slip faulting and escape tectonics in frontal Dinarides-Hellenides, Croatia, Yugoslavia, Albania, and Greece, AAPG Bulletin, 86(9), 1659-1671.

Pincha, F. J. (2011), Late orogenic faulting of the foreland plate: An important component of petroleum systems in orogenic belts and their forelands, AAPG Bulletin, 95(6), 957-981.

Pullen, A., P. Kapp, G. E. Gehrels, J. D. Vervoort, and L. Ding (2008), Triassic continental subduction in central Tibet and Mediterranean-style closure of the Paleo-Tethys Ocean, Geology, 36, 351-354.

Qinghai Bureau of Geology and Mineral Resources (QBGMR) (1991), Regional Geology of Qinghai Province, Geological Publishing House, Beijing.

Ratschbacher, L., B. R. Hacker, L. E. Webb, M. O. McWilliams, T. Ireland, S. Dong, A. Calvert, D. Chateigner, and H.-R. Wink (2000), Exhumation of the ultrahigh-pressure continental crust in east central China cretaceous and Cenozoic unroofing and the Tan-Lu Fault, J. Geophys. Res., 105(B6), $13,303-13,338$

Ratschbacher, L., B. R. Hacker, A. Calvert, L. E. Webb, J. C. Grimmer, M. O. McWilliams, T. Ireland, S. Dong, and J.-M. Hu (2003), Tectonics of the Qinling (Central China): Tectonostratigraphy, geochronology, and deformation history, Tectonophysics, 366, 1-53.

Reiners, P. W., and T. A. Ehlers (2005), Low-Temperature Thermochronology: Techniques, Interpretations, and Applications, Rev. Mineral. Geochem., 58, edited by P. W. Reiners, and T. A. Ehlers, p. 1-18, Mineralogical Society of America, Chantilly, VA.

Reiners, P. W., K. A. Farley, and H. J. Hickes (2002), He diffusion and (U$\mathrm{Th}) /$ He thermochronometry of zircon: Initial results from Fish Canyon Tuff and Gold Butte, Tectonophysics, 349, 297-308.

Reiners, P. W., T. L. Spell, S. Nicolescu, and K. A. Zanetti (2004), Zircon $(\mathrm{U}-\mathrm{Th}) / \mathrm{He}$ thermochronometry: He diffusion and comparisons with ${ }^{40} \mathrm{Ar}{ }^{39}$ Ar dating, Geochim. Cosmochim. Acta, 68, 1857-1887.

Rey, P., O. Vanderhaeghe, and C. Teyssier (2001), Gravitational collapse of the continental crust: Definition, regimes, and modes, Tectonophysics, 342, 435-449.

Ritts, B. D., Y. Yue, S. Graham, E. R. Sobel, O. A. Abbink, and D. Stockli (2008), From sea level to high elevation in 15 million years: Uplift history of the northern Tibetan Plateau margin in the Altun Shan, Am. J. Sci., 308, 657-678.

Rowley, D. B. (1996), Age of initiation of collision between India and Eurasia: A review of stratigraphic data, Earth Planet. Sci. Lett., 145, 1-13.

Rowley, D. B. (1998), Minimum age of initiation of collision between India and Eurasia north of Everest based on the subsidence history of the Zhepure Mountain section, J. Geol., 106, 220-235.

Royden, L. H., B. C. Burchfiel, R. W. King, E. Wang, Z. Chen, F. Shen, and Y. Liu (1997), Surface deformation and lower crustal flow in Eastern Tibet, Science, 276(5313), 788-790.

Royden, L. H., B. C. Burchfiel, and R. D. van der Hilst (2008), The geological evolution of the Tibetan Plateau, Science, 321(5892), 1054-1058.

Schoenbohm, L. M., B. C. Burchfiel, and C. Liangzhong (2006), Propagation of surface uplift, lower crustal flow, and Cenozoic tectonics of the southeast margin of the Tibetan Plateau, Geology, 34, 813-816, doi:10.1130/G22679.1.

Searle, M., J. Elliott, R. Phillips, and S. L. Chung (2011), Crustal-lithospheric structure and continental extrusion of Tibet, J. Geologic. Soc., 168, 633-672. Sengor, A. M. C., N. Gorur, and F. Saroglu (1985), Strike-slip faulting and related basin formation in zones of tectonic escape: Turkey as a case study, 
in Strike-Slip Faulting and Basin Formation, Spec. Publ. Soc. Econ. Paleontol. Mineral., 37, edited by K. T. Biddke and N. Christie-Blick, pp. 227-264.

Sobel, E. R., N. Arnaud, M. Jolivet, B. D. Ritts, and M. Brunel (2001), Jurassic to Cenozoic exhumation history of the Altyn Tagh range, northwest China constrained by ${ }^{40} \mathrm{Ar} /{ }^{39} \mathrm{Ar}$ and apatite fission track thermochronology, in Paleozoic and Mesozoic Tectonic Evolution of Central And Eastern Eurasia: From Continental Assembly to Intracontinental Deformation: edited by M. S. Hendrix and G. A. Davis, Mem. Geol. Soc. Am., 194, $247-268$.

Sonder, L. J., P. C. England, B. P. Wernicke, and R. L. Christiansen (1987) A physical model for Cenozoic extension of western North America, Geol. Soc. London Spec. Pub., 28, 187-201.

Spotila, J. A., K. A. Farley, and K. Sieh (1998), Uplift and erosion of the San Bernardino Mountains associated with transpression along the San Andreas Fault, California, as constrained by radiogenic helium thermochronometry, Tectonics, 17, 360-378.

Spotila, J. A., K. A. Farley, J. D. Yule, and P. W. Reiners (2001), Nearfield transpressive deformation along the San Andreas fault zone in southern California, based on exhumation constrained by (U-Th)/He dating, J. Geophys. Res., 106(B12), 30,909-30,922, doi:10.1029/ 2001 JB000348.

Spotila, J. A., N. Niemi, R. Brady, M. House, J. Buscher, and M. Oskin (2007), Long-term continental deformation associated with transpressive plate motion: The San Andreas Fault, Geology, 35, 967-970.

Stirling, M. W., S. G. Wesnousky, and K. Shimazaki (1996), Fault trace complexity, cumulative slip, and the shape of the magnitude-frequency distribution for strike-slip faults: A global survey, Geophys. J. Int., 124, 833-868.

Sylvester, A. G. (1988), Strike-slip faults, Geol. Soc. Am. Bull., 100(11), 1666-1703, doi:10.1130/0016-7606.

Tapponnier, P., Z. Q. Xu, F. Roger, B. Meyer, N. Arnaud, G. Wittlinger, and J. S. Yang (2001), Geology: Oblique stepwise rise and growth of the Tibet Plateau, Science, 294, 1671-1677.

Taylor, M., and A. Yin (2009), Active structures of the Himalayan-Tibetan orogeny and their relationships to earthquake distribution, contemporary strain field, and Cenozoic volcanism, Geosphere, 5, 199-214.

Taylor, M., A. Yin, F. J. Ryerson, P. Kapp, and L. Ding (2003), Conjugate strike-slip faulting along the Bangong-Nujiang suture zone accommodates coeval east-west extension and north-south shortening in the interior of the Tibetan Plateau, Tectonics, 22(4), 1044, doi:10.1029/ 2002TC001361

Teyssier, C., B. Tikoff, and M. Markley (1995), Oblique plate motion and continental tectonics, Geology, 23(5), 447-450.

Umhoefer, P. J., D. L. Whitney, C. Teyssier, A. K. Fayon, G. Cesale, and M. T. Heizler (2007), Yo-yo tectonics in a wrench zone, Central Anatolian fault zone, Turkey, GSA Spec. Pap., 434, 35-57, doi:10.1130/ 2007.2434(03).

Van der Woerd, J., F. J. Ryerson, P. Tapponnier, Y. Gaudemer, R. Finkel, A. S. Meriaux, M. Caffee, G. G. Zhao, and Q. L. He (1998), Holocene left-slip rate determined by cosmogenic surface dating on the Xidatan segment of the Kunlun fault (Qinghai, China), Geology, 26, 695-698.

Van der Woerd, J., F. J. Ryerson, P. Tapponnier, A. S. Meriaux, Y. Gaudemer, B. Meyer, R. C. Finkel, M. W. Caffee, G. G. Zhao, and Z. Q. Xu (2000), Uniform Slip-Rate along the Kunlun Fault: Implications for seismic behaviour and large-scale tectonics, Geophys. Res. Lett., 27, 2353-2356.

Van Der Woerd, J., P. Tapponnier, F. J. Ryerson, A. S. Meriaux, B. Meyer, Y. Gaudemer, R. C. Finkel, M. W. Caffee, G. G. Zhao, and Z. Q. Xu (2002), Uniform postglacial slip-rate along the central $600 \mathrm{~km}$ of the Kunlun Fault (Tibet), from Al-26, Be-10, and C-14 dating of riser offsets, and climatic origin of the regional morphology, Geophys. J. Int., 148, 356-388.

Vincent, S. J., and M. B. Allen (1999), Evolution of the Minle and Chaoshui Basins, China: Implications for Mesozoic strike-slip basin formation in central Asia, Geol. Soc. Am. Bull., 111, 725-742.

Wagner, G. A., and G. M. Reimer (1972), Fission track tectonics: The tectonic interpretation of fission track apatite ages, Earth Planet. Sci. Lett., 14(2), 263-268.

Wang, E. C., and B. C. Burchfiel (2004), Late Cenozoic right-lateral movement along the Wenquan fault and associated deformation: Implications for the kinematic history of the Qaidam Basin Northeastern Tibetan Plateau, Int. Geol. Rev., 46, 861-879.

Wang, F., C. H. Lo, Q. Li, M. H. Yeh, J. Wan, D. Zheng, and E. Wang (2004), Onset timing of significant unroofing around Qaidam basin, northern Tibet, China: Constraints from ${ }^{40} \mathrm{Ar} /{ }^{39} \mathrm{Ar}$ and FT thermochronology on granitoids, J. Asian Earth Sci., 24(1), 59-69.

Wang, W., P. Z. Zhang, E. Kirby, L. H. Wang, G. L. Zhang, D. W. Zheng, and C. Z. Chai (2011a), A revised chronology for
Tertiary sedimentation in the Sikouzi basin: Implications for the tectonic evolution of the northeastern corner of the Tibetan Plateau, Tectonophysics, 505, 100-114.

Wang, X., M. Zattin, J. Li, C. Song, T. Peng, S. Liu, and B. Liu (2011b), Eocene to Pliocene exhumation history of the Tianshui-Huicheng region determined by apatite fission track thermochronology of the northeastern Tibetan Plateau margin, J. Asian Earth Sci., 42(1-2), 97-110.

Wilcox, R. E., T. P. Harding, and D. R. Seely (1973), Basic wrench tectonics, AAPG Bulletin, 57(1), 74-96.

Wilson, C. J. L., and A. P. Fowler (2011), Denudational response to surface uplift in east Tibet: Evidence from apatite fission-track thermochronology, Bull. Geol. Soc. Am., doi:10.1130/B30331.1.

Wolf, R. A., K. A. Farley, and L. T. Silver (1996), Helium diffusion and low-temperature thermochronometry of apatite, Geochim. Cosmochim. Acta, 60, 4231-4240.

Wolf, R. A., K. A. Farley, and D. M. Kass (1998), Modeling of the temperature sensitivity of the apatite (U-Th)/He thermochronometer, Chem. Geol., 148, 105-114.

Woodcock, N. H., and M. Fischer (1986), Strike-slip duplexes, J. Struct. Geol., 8, 725-735.

Wu, Z., P. Ye, B. J. Patrick, D. Hu, W. Zhao, and Z. Wu (2009), Late Oligocene-Early Miocene thrusting in southern East Kunlun Mountains, northern Tibetan Plateau, J. Earth Sci., 20(2), 381-390.

Yan, M., R. VanderVoo, X. Fang, J. M. Parés, and D. K. Rea (2006), Paleomagnetic evidence for a mid-Miocene clockwise rotation of about 25 of the Guide Basin area in NE Tibet, Earth Planet. Sci. Lett., 241, 234-247.

Yin, A. (2010), Cenozoic tectonic evolution of Asia, a preliminary synthesis, Tectonophysics, 488, 293-325.

Yin, A., T. M. Harrison, F. J. Ryerson, W. Chen, W. S. F. Kidd, and P. Copeland (1994), Tertiary structural evolution of the Gandese thrust system in southern Tibet, J. Geophys. Res., 99, 18,175-18,201.

Yin, A., et al. (2002), Tectonic history of the Altyn Tagh fault system in northern Tibet inferred from Cenozoic sedimentation, Geol. Soc. Am. Bull., 114, 1257-1295.

Yin, A., Y. Dang, M. Zhang, M. W. McRivette, W. P. Burgess, and X. Chen (2007), Cenozoic tectonic evolution of Qaidam basin and its surrounding regions (part 2): Wedge tectonics in southern Qaidam basin and the Eastern Kunlun Range, Geol. Soc. Am. Spec. Pap., 433, 369-390.

Yin, A., Y. Q. Dang, L. C. Wang, W. M. Jiang, S. P. Zhou, X. H. Chen, G. E. Gehrels, and M. W. McRivette (2008a), Cenozoic tectonic evolution of Qaidam basin and its surrounding regions (Part 1): The southern Qilian Shan-Nan Shan thrust belt and northern Qaidam basin, Geol. Soc. Am. Bull., 120, 813-846.

Yin, A., Y. Q. Dang, M. Zhang, X. H. Chen, and M. W. McRivette (2008b), Cenozoic tectonic evolution of the Qaidam basin and its surrounding regions (part 3): Structural geology, sedimentation, and regional tectonic reconstruction, Geol. Soc. Am. Bull., 120, 847-876.

Yuan, W., J. Dong, W. Shicheng, and A. Carter (2006), Apatite fission track evidence for Neogene uplift in the eastern Kunlun Mountains, north Qinghai-Tibet Plateau, China, J. Asian Earth Sci., 27, 847-856.

Yuan, D. Y., J. D. Champagnac, W. P. Ge, P. Molnar, P. Z. Zhang, W. J. Zheng, H. P. Zhang, and X. W. Liu (2011), Late Quaternary right-lateral slip rates of faults adjacent to the lake Qinghai, northeastern margin of the Tibetan Plateau, Geol. Soc. Am. Bull., doi:10.1130/B30315.1.

Yue, Y. J., B. D. Ritts, A. D. Hanson, and S. A. Graham (2004), Sedimentary evidence against large strike-slip translation on the Northern Altyn Tagh fault, NW China, Earth Planet. Sci. Lett., 228, 311-323.

Zeitler, P. K., A. L. Herczeg, I. Mcdougall, and M. Honda (1987), U-Th-He dating of apatite-A potential thermochronometer, Geochim. Cosmochim. Acta, 51, 2865-2868.

Zhai, Y., and T. Cai (1984), The Tertiary system of Gansu province, Gansu Geol., 1984, 1-40.

Zhang, P. Z., B. C. Burchfiel, P. Molnar, W. Q. Zhang, D. C. Jiao, Q. D. Deng, Y. P. Wang, L. Royden, and F. M. Song (1991), Amount and style of late Cenozoic deformation in the Liupan Shan area, Ningxia Autonomous region, China, Tectonics, 10, 1111-1129.

Zhang, P. Z., Z. Shen, M. Wang, W. J. Gan, R. Burgmann, and P. Molnar (2004), Continuous deformation of the Tibetan Plateau from global positioning system data, Geology, 32, 809-812.

Zhang, P. Z., P. Molnar, and X. Xu (2007), Late Quaternary and present-day rates of slip along the Altyn Tagh Fault, northern margin of the Tibetan Plateau, Tectonics, 26, TC5010, doi:10.1029/ 2006TC002014.

Zhang, H. P., W. H. Craddock, R. O. Lease, W. Wang, D. Y. Yuan, P. Z. Zhang, P. Molnar, D. W. Zheng, and W. J. Zheng (2011), Magnetostratigraphy of the Neogene Chaka basin and its implications for mountain building processes in the north-eastern Tibetan Plateau, Basin Res., doi:10.1111/j.1365-2117.2011.00512.x. 


\section{DUVALL ET AL: TIMING OF STRIKE-SLIP FAULTING TIBET}

Zheng, D. W., P. Z. Zhang, J. L. Wan, C. Y. Li, and J. X. Cao (2003), Late Cenozoic deformation subsequence in northeastern margin of TibetDetrital AFT records from Linxia Basin, Sci. China Earth Sci., 46, $266-275$.

Zheng, D. W., P. Z. Zhang, J. L. Wan, D. Y. Yuan, C. Y. Li, G. M. Yin, G. L. Zhang, Z. C. Wang, M. Min, and J. Chen (2006), Rapid exhumation at similar to $8 \mathrm{Ma}$ on the Liupan Shan thrust fault from apatite fission-track thermochronology: Implications for growth of the northeastern Tibetan Plateau margin, Earth Planet. Sci. Lett., 248(1-2), 198-208.
Zheng, D., M. K. Clark, P. Zhang, W. Zheng, and K. A. Farley (2010), Erosion, fault initiation and topographic growth of the North Qilian Shan (northern Tibetan Plateau), Geosphere, 6(6), 937-941.

Zhou, J. X., F. Y. Xu, T. C. Wang, A. F. Cao, and C. M. Yin (2006), Cenozoic deformation history of the Qaidam Basin, NW China: Results from cross-section restoration and implications for Qinghai-Tibet Plateau tectonics, Earth Planet. Sci. Lett., 243, 195-210.

Zhu, L., T. J. Owens, and G. E. Randall (1995), Lateral variation in crustal structure of the northern Tibetan Plateau inferred from teleseismic receiver functions, Bull. Seismol. Soc. Am., 85, 1531-1540. 